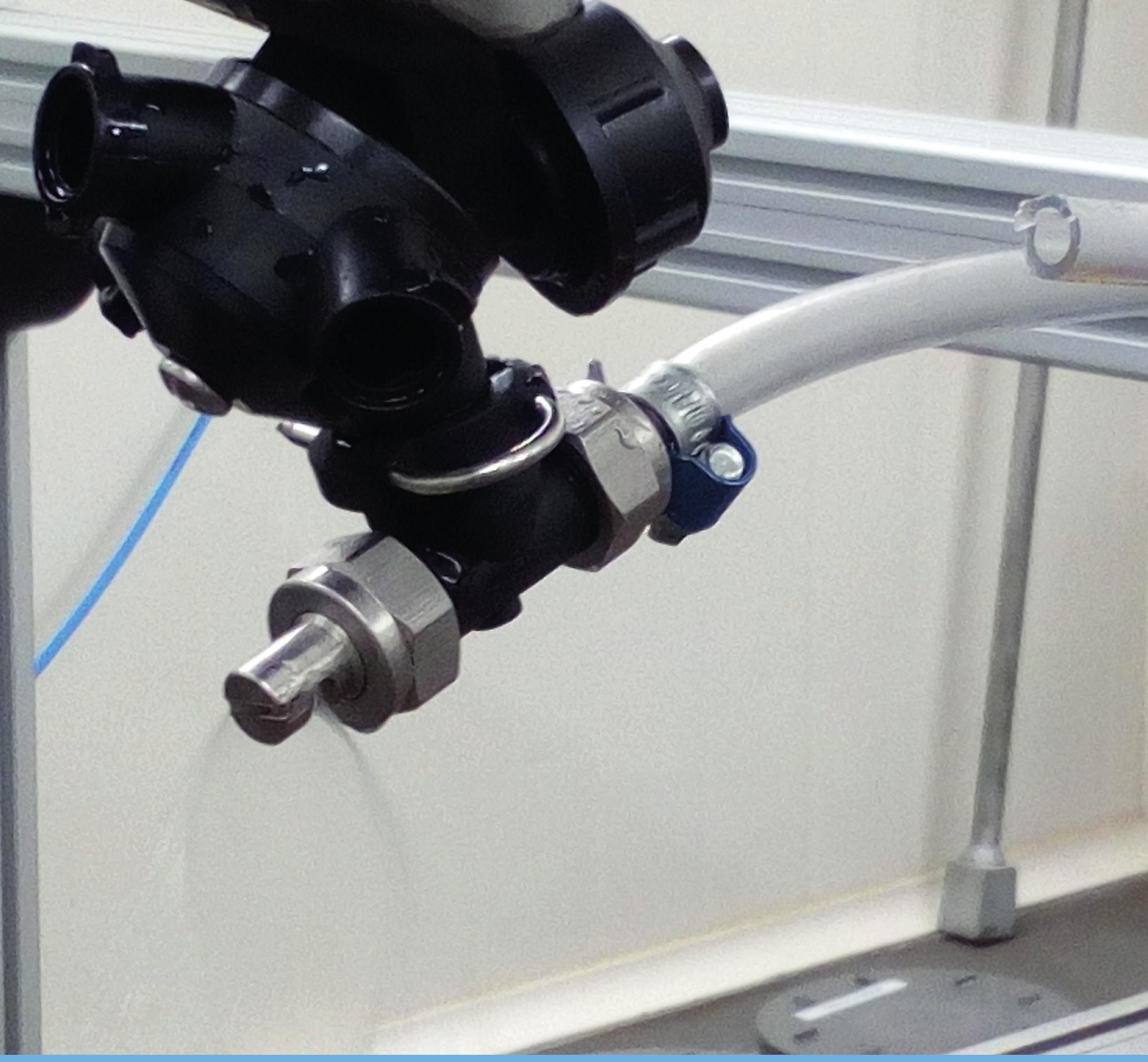

Onderzoek aan spuitdoppen voor het HTA DriftControlPlus systeem met verlaagde spuitboom voor classificatie op basis van driftgevoeligheid

H.J. Holterman, J.C. van de Zande

WAGENINGEN

UNIVERSITY \& RESEARCH 



\section{Onderzoek aan spuitdoppen voor het HTA DriftControlPlus systeem met verlaagde spuitboom voor classificatie op basis van driftgevoeligheid}

H.J. Holterman, J.C. van de Zande

Dit onderzoek is in opdracht van Agrifac Machinery BV uitgevoerd door de Stichting Wageningen Research (WR), business unit Agrosysteemkunde, onder projectnummer 3710.469600 . 
Holterman, H.J., J.C. van de Zande, 2020. Onderzoek aan spuitdoppen voor het HTA DriftControlPlus systeem met verlaagde spuitboom voor classificatie op basis van driftgevoeligheid. Wageningen Research, Rapport WPR-1022. 32 blz.; 7 fig.; 6 tab.; 17 ref.

Dit rapport is gratis te downloaden op https://doi.org/10.18174/533345

Bij het HTA DriftControlPlus systeem van Agrifac met de lucht-vloeistofdoppen HTA 10/39 TKSS4 zijn door variatie van vloeistofdruk en luchtdruk de druppelgrootteverdeling en vloeistofafgifte min of meer onafhankelijk van elkaar in te stellen. In deze studie is een groot aantal drukcombinaties door meting en simulaties onderzocht wat betreft driftdepositie en driftreducties op een standaardsloot, bij een volvelds bespuiting met een spuitboomhoogte van $0,30 \mathrm{~m}$ en dopafstand van 0,25 $\mathrm{m}$ en een $8^{\circ}$ gekantelde HTA-dop zonder lucht als randmodus-dop voor de perceelrandbespuiting gebruikt. Uit de verscheidenheid aan drukcombinaties en de daarbij berekende driftreducties ten opzichte van een referentiebespuiting op een standaardsloot, is een modelmatig verband afgeleid waarmee te bepalen is welke combinaties van vloeistofdruk en luchtdruk toegepast kunnen worden om driftreducties van $75 \%, 90 \%$ en $95 \%$ te verkrijgen. Voor een driftreductie van $75 \%$ en $90 \%$ is de maximale vloeistofdruk $600 \mathrm{kPa}$. Voor een driftreductie van $95 \%$ is de maximale vloeistofdruk $400 \mathrm{kPa}$.

Trefwoorden: spuitdop, lucht-vloeistof mengdop, twin-fluid, HTA, driftreductie

(C) 2020 Wageningen, Stichting Wageningen Research, Wageningen Plant Research, Business unit Agrosysteemkunde, Postbus 16, 6700 AA Wageningen; T 03174807 00; www.wur.nl/plant-research

KvK: 09098104 te Arnhem

VAT NL no. 8113.83.696.B07

Stichting Wageningen Research. Alle rechten voorbehouden. Niets uit deze uitgave mag worden verveelvoudigd, opgeslagen in een geautomatiseerd gegevensbestand, of openbaar gemaakt, in enige vorm of op enige wijze, hetzij elektronisch, mechanisch, door fotokopieën, opnamen of enige andere manier zonder voorafgaande schriftelijke toestemming van Stichting Wageningen Research.

Stichting Wageningen Research is niet aansprakelijk voor eventuele schadelijke gevolgen die kunnen ontstaan bij gebruik van gegevens uit deze uitgave.

Rapport WPR-1022

Foto omslag: H.J. Holterman 


\section{Inhoud}

Woord vooraf $\quad 5$

$\begin{array}{ll}\text { Samenvatting } & 7\end{array}$

$\begin{array}{ll}\text { Summary } & 9\end{array}$

$\begin{array}{lr}1 & 11\end{array}$

$2 \quad$ Materiaal en methoden $\quad 12$

2.1 Selectie van drukcombinaties 13

2.2 Meetmethodiek druppelgrootte 13

$\begin{array}{ll}2.3 \text { Modelberekeningen } & 15\end{array}$

$\begin{array}{ll}2.4 & \text { Indeling in driftreductieklassen }\end{array}$

3

$\begin{array}{ll}\text { Meetresultaten } & 17\end{array}$

$\begin{array}{lll}3.1 & \text { Spuitbordmetingen } & 17\end{array}$

3.2 Vloeistofafgifte 18

$\begin{array}{ll}3.3 & \text { Druppelgroottespectrum }\end{array}$

$\begin{array}{ll}3.4 & \text { Modelberekeningen IDEFICS }\end{array}$

\begin{tabular}{llr}
\hline & Discussie & 23
\end{tabular}

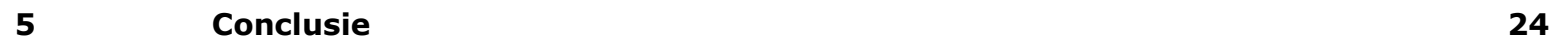

$\begin{array}{ll}\text { Literatuur } & 25\end{array}$

Bijlage 1 Overzicht metingen van druppelgroottes 26

Bijlage 2 Overzicht aanvullende metingen van druppelgroottes 30 



\section{Woord vooraf}

Dit onderzoek naar de driftreducerende eigenschappen van spuitdoppen volgens het lucht-vloeistof mengsysteem HTA DriftControlPlus is uitgevoerd in nauwe samenwerking met

dhr. Melle van der Molen en dhr. Doeko Blaauw van Agrifac Machinery BV. Al doende heeft deze samenwerking geleid tot aanpassingen in de meetopdracht waarvan dit rapport het uiteindelijke resultaat is geworden. Geen 'gewoon' meetrapport, maar een rapport met perspectief op verder toepassingen en mogelijkheden. 


\section{Samenvatting}

Bij het HTA DriftControlPlus systeem van Agrifac met de lucht-vloeistofdoppen HTA 10/39 TKSS4 zijn door variatie van vloeistofdruk en luchtdruk de druppelgrootteverdeling en vloeistofafgifte min of meer onafhankelijk van elkaar in te stellen. In deze studie is een groot aantal drukcombinaties door meting en simulaties onderzocht wat betreft driftdepositie en driftreducties op een standaardsloot, bij een volvelds bespuiting met een spuitboomhoogte van $0,30 \mathrm{~m}$ en dopafstand van 0,25 m en een $8^{\circ}$ gekantelde HTA-dop zonder lucht als randmodus-dop op de perceelrand gebruikt. Uit de verscheidenheid aan drukcombinaties en de daarbij berekende driftreducties ten opzichte van een referentiebespuiting op een standaardsloot, is een modelmatig verband afgeleid waarmee te bepalen is welke combinaties van vloeistofdruk en luchtdruk toegepast kunnen worden om driftreducties van $75 \%, 90 \%$ en $95 \%$ te verkrijgen. Voor een driftreductie van $75 \%$ en $90 \%$ is de maximale vloeistofdruk $600 \mathrm{kPa}$. Voor een driftreductie van $95 \%$ is de maximale vloeistofdruk $400 \mathrm{kPa}$. 


\section{Summary}

With Agrifac's new HTA DriftControlPlus system using air-liquid spray nozzles HTA 10/39 TKSS4, the drop size distribution of the spray and the flow rate can be controlled independently. In this study a number of air-liquid pressure combinations has been investigated by measuring spray distributions, drop size distributions and simulating downwind spray drift deposits. The spray drift reductions on a standardized ditch were determined for field applications with a boom height of 0,30 $\mathrm{m}$ and nozzle distance of 0,25 $\mathrm{m}$ along the sprayer boom. An HTA nozzle without air inlet and rotated by $8^{\circ}$, was used as an end nozzle. The large number of air-liquid combinations and their resulting drift reductions were used to derive a generic model to determine appropriate combinations of air pressure and liquid pressure to obtain drift reduction levels of $75 \%, 90 \%$ and $95 \%$. The maximum liquid pressure at drift reduction levels $75 \%$ and $90 \%$ is $600 \mathrm{kPa}$. At drift reduction level $95 \%$ the maximum liquid pressure is $400 \mathrm{kPa}$. 


\section{$1 \quad$ Inleiding}

Het Activiteitenbesluit Milieubeheer (I\&M, 2012, 2017a) bepaalt dat bij bespuitingen van een gewas met veldspuitapparatuur het gehele veld bespoten moet worden met een $75 \%$ driftreducerende techniek (DRT75). Bijvoorbeeld een standaard veldspuit uitgerust met 75\% driftreducerende doppen (DRD75). In de "Beoordelingssystematiek emissiereducerende maatregelen open teelt" (TCT, 2017) en de daarin beschreven testmethode "Meetprotocol vaststellen driftreductie spuitdoppen-versie 1 juli 2017" (I\&M, 2017b) worden de eisen beschreven waaraan de spectra van spuitdoppen moeten voldoen om als driftarm te worden aangemerkt. Ook is hierin de toe te passen meetmethode vastgelegd. Driftarme doppen kunnen onderling behoorlijk verschillen in werkelijke driftreductie. Door de Technische Commissie Techniekbeoordeling (TCT, 2019) worden spuitdop-druk combinaties daarom ingedeeld in driftreductieklassen (DRD50, DRD75, DRD90, DRD95) voor gebruik in de verschillende driftreducerende technieken (DRT) en ter bepaling van de teeltvrije zone bij intensief gespoten gewassen.

Dit onderzoek omvat de lucht-vloeistofdoppen van het type Agrifac HTA 10/39-TKSS4. Voor een groot aantal combinaties van vloeistofdruk en luchtdruk is de vloeistofverdeling gemeten op een spuitbord (ISO5682-1, 2014; ISO5682-2; 2017). Volgens ISO 16119-2, 2013 moet de variatiecoëfficiënt van deze vloeistofverdeling kleiner dan 7\% bedragen; ISO 16122-2, 2015 noemt een variatiecoëfficiënt kleiner dan 10\%, overeenkomstig het TCT-DRD protocol (I\&M, 2017b). Gemeten verdelingen die een variatiecoëfficiënt kleiner dan $9 \%$ opleverden, zijn verder uitgewerkt in druppelgroottemetingen. De resulterende druppelgroottespectra zijn gebruikt in berekeningen met het driftmodel IDEFICS (Holterman et al., 1997) om de drift te bepalen naar het wateroppervlak van een standaardsloot. Daarbij was de spuitboomhoogte $30 \mathrm{~cm}$ boven het gewas terwijl de afstand tussen de spuitdoppen $25 \mathrm{~cm}$ bedroeg. Aan de hand van de daaruit voortvloeiende driftreductie ten opzichte van een referentiebespuiting zijn de lucht-vloeistofdoppen voor de diverse vloeistofdruk-luchtdrukcombinaties ingedeeld naar driftreductieklassen 75, 90 en 95\%, analoog aan de methode beschreven door Porskamp et al. (1999), ISO22369 (2006) en het meetprotocol voor de bepaling en de classificatie van de driftreductie van spuitdoppen (I\&M, 2017b). Tevens is het verband onderzocht tussen de verschillende drukcombinaties en driftreducties, om zo tot een meer generiek model te komen voor verdere toepassingen in het HTA DriftControlPlus systeem. 


\section{Materiaal en methoden}

Van het doptype Agrifac HTA 10/39 TKSS4 (kortweg HTA-doppen; Figuur 1) werden het druppelgroottespectrum en de druppelsnelheden bepaald met behulp van de optische methode phasedoppler anemometrie (PDA), bij geselecteerde combinaties van vloeistofdruk en luchtdruk. Ook het druppelgroottespectrum van de grensdop Fijn/Midden (F/M; Lurmark 31-03-F110 bij een spuitdruk van $300 \mathrm{kPa}$ ) van de klassenindeling volgens de British Crop Protection Council (BCPC, Southcombe et al., 1997) is op soortgelijke wijze gemeten; deze referentiedop wordt verder aangeduid als BCPC F/M. Als spuitvloeistof werd leidingwater toegepast. De resulterende spectra werden gebruikt in het simulatiemodel IDEFICS (versie 0.434; Holterman et al., 1997) om de verwachte drift naar een standaardsloot te berekenen voor een gestandaardiseerde volvelds bespuiting. De evaluatiestrook voor driftdepositie komt overeen met de positie van het wateroppervlak; dit is 1,625-2,625 $\mathrm{m}$ vanaf de gewasrand. De simulaties met de onderzochte doptypen betrof een spuitboomhoogte van 0,30 m boven het gewas en een dopafstand van 0,25 m. Voor een goed aansluiting van het spuitbeeld voor verschillende spuitgangen, is de strook tussen spuitgangen in principe 0,25 m smaller dan voor een standaardbespuiting met dopafstand 0,50 m. Hieruit is af te leiden dat in de eerste spuitgang de buitenste spuitdop de helft hiervan, dus 0,125 m, dichter bij de gewasrand geplaatst moet zijn dan de buitenste dop bij een standaardbespuiting. Voor de referentiesituatie (BCPC F/M) bevindt de eerste spuitdop zich 0,50 m binnen de gewasrand, zodat de evaluatiestrook 2,125-3,125 m vanaf deze dop ligt (zie ook Figuur 4). Voor de geteste situaties met dopafstand 0,25 m bevindt de eerste dop zich op 0,375 m binnen de gewasrand; de evaluatiestrook ligt dan op 2,000-3,000 m vanaf de buitenste dop (zie ook Figuur 5).

Driftdepositie wordt uitgedrukt als percentage van de uitgebrachte dosering per oppervlakte-eenheid. Aan de hand van de berekende drift van de BCPC F/M referentiedop en de geteste drukcombinaties met de HTA-doppen werden de combinaties beoordeeld naar het systeem van driftreductieklassen (volgens ISO22369 t.o.v. de BCPC F/M grensdop) volgens het classificatiesysteem van de TCT (TCT, 2017).

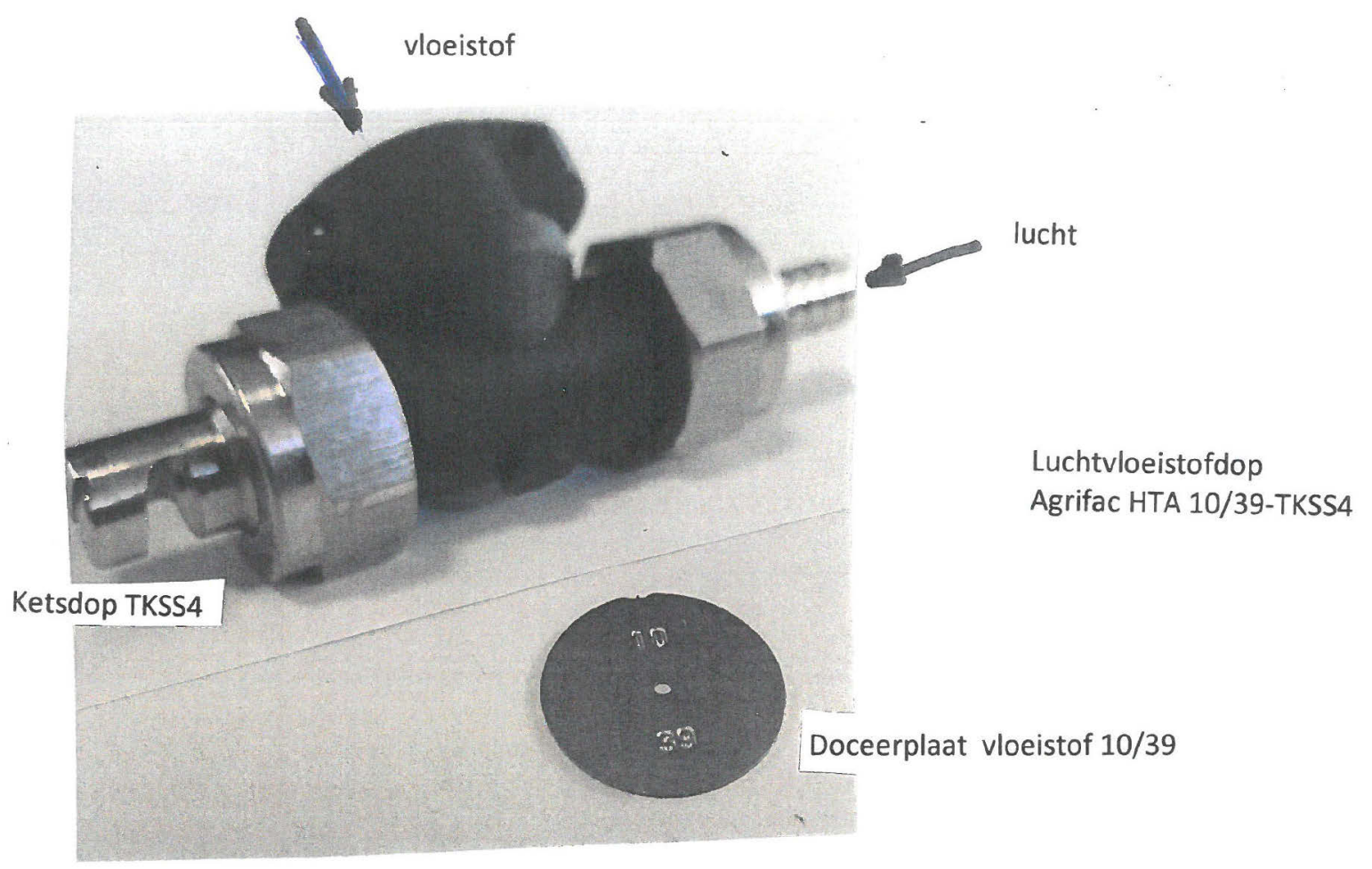

Figuur 1 Doptype Agrifac HTA 10/39 TKSS4 met lucht- en vloeistofaans/uiting. Doceerplaatje komt bovenin de aansluiting voor de vloeistof (Bron: Agrifac). 


\subsection{Selectie van drukcombinaties}

Op het spuitbord zijn 10 HTA-doppen op onderlinge afstand van 0,25 m geplaatst. De vloeistofverdeling is bepaald bij diverse combinaties van vloeistofdruk en luchtdruk. Het spuitbord had gootjes van 0,025 m breed. Voor de bepaling van de variatiecoëfficiënt (VC) zijn steeds 4 gootjes samengenomen om een effectieve gootbreedte van $0,10 \mathrm{~m}$ te verkrijgen. Vervolgens is de VC berekend over een breedte van 1,00 $\mathrm{m}$ uit het midden van de verdeling. Alleen de combinaties die een variatiecoëfficiënt (VC) van minder dan $10 \%$ opleverden, zijn verder uitgewerkt in deze studie om uiteindelijk drift en driftreducties te bepalen voor een volvelds bespuiting.

\subsection{Meetmethodiek druppelgrootte}

Van 10 exemplaren van de HTA-doppen is de vloeistofafgifte bepaald bij een bepaalde vloeistof- en luchtdruk. Uit deze waarden is de mediaan bepaald om vervolgens de 3 doppen te kunnen selecteren, waarvan de afgifte het dichtst bij de mediaan lag. Van de geselecteerde 3 doppen werden vervolgens het druppelgroottespectrum en druppelsnelheden bepaald met een Phase Doppler Particle Analyzer (PDPA, TSI). De spuitvloeistof hierbij is leidingwater van $20^{\circ} \mathrm{C}$. Voor de HTA-doppen werd tevens perslucht gebruikt, dat door middel van een manuele regelaar op de juiste druk kon worden gebracht. De meetruimte werd ingesteld op een temperatuur van $20^{\circ} \mathrm{C}$ en een relatieve luchtvochtigheid van $70 \%$.

Bij de metingen van het druppelgroottespectrum beschreef de doppositie een patroon van 11 parallelle banen (Figuur 2). De lengte van de banen en hun onderlinge afstand werden per situatie zodanig ingesteld, dat het banenpatroon het totale spuitpatroon goed afdekte. De snelheid waarmee het banenpatroon werd doorlopen, werd daarbij zodanig afgesteld, dat ten minste 10000 druppels per meting werden gemeten. Voor de HTA-doppen was de dophoogte $30 \mathrm{~cm}$ boven het meetvlak; voor de BCPC F/M referentiedop was de hoogte 0,35 m. Volgens het TCT meetprotocol voor spuitdoppen moeten alle doppen op gelijke hoogte gemeten worden (I\&M, 2017b). Dit bleek door de verlengde constructie van de dophouder van de HTA-doppen moeilijk te realiseren (zie ook Figuur 3). Overigens schrijft het meetprotocol voor dat dophoogtes mogen liggen tussen 0,30 en 0,50 m, omdat dit geen significante invloed op het druppelgroottespectrum heeft. $\mathrm{Er}$ is daarom geen reden te veronderstellen dat de druppelgroottemetingen van de HTA-doppen op 0,30 m dophoogte significant verschillen van metingen die op 0,35 m zouden zijn uitgevoerd. De meethoogte boven de vloer bedroeg 0,70 m. De HTA-doppen zijn in feite ketsdoppen (TKSS4), waarvoor de 'flat-fan' spuitkegel gewoonlijk niet verticaal naar beneden gericht is, maar over een kleine hoek ('tilthoek') naar achteren gericht is. Daarom werd de dophouder gekanteld, zodat de spuitkegel verticaal was gericht gedurende de metingen met de PDPA (Figuur 3). Zowel de tophoek van de spuitkegel als de tilthoek werd voor elke dop bij elke drukcombinatie geometrisch bepaald.

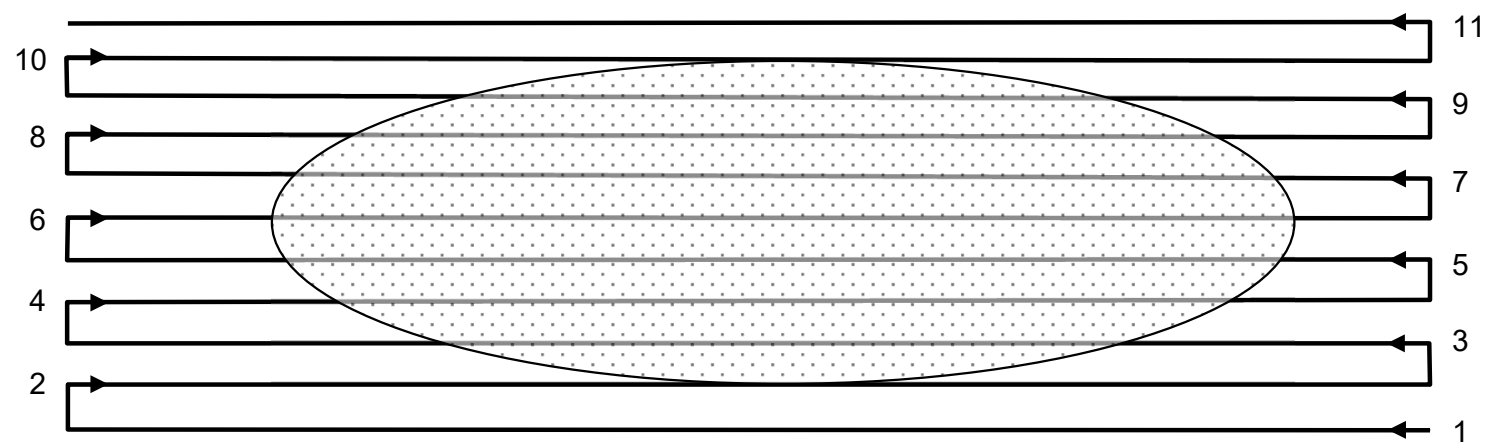

Figuur 2 Patroon van de banen voor het scannen van de druppelgrootteverdeling in een horizontaal vlak 0,50 m onder een spuitkegel van een spleetdop. De baanlengte en de onderlinge baanafstand werden aangepast aan de spuitpatronen van de te meten doppen. Baan 6 is de middelste baan loodrecht onder de dop. 
Voor geselecteerde combinaties van vloeistof- en luchtdruk werd van elk van de drie doppen de druppelgroottebepaling in drievoud uitgevoerd. Daarnaast zijn voor enkele tussenliggende combinaties aanvullende metingen uitgevoerd, om een beter beeld te krijgen van het generieke verband tussen vloeistof- en luchtdruk en driftreductie. Deze extra combinaties zijn niet volledig bemeten, maar van elk van de drie geselecteerde doppen is slechts 1 meting gedaan voor de druppelgrootteverdeling.

Er is besloten de HTA-doppen ook als randmodus-dop op het einde van de spuitboom voor de bespuiting van de perceelrand te gebruiken. In dat geval wordt de luchtdruk op 0 ingesteld, om een zo grof mogelijk spuitbeeld te verkrijgen. Hiertoe werd de luchtinlaat afgesloten door een kort stukje slang te monteren op de inlaat en het andere einde van de slang dicht te knijpen met een slangklem. De metingen van de HTA als randmodus-dop omvatten de geselecteerde 3 doppen die elk in tweevoud gemeten werden. Verder is voor de randmodus-dop van belang hoe de spuitvloeistof binnen de spuitkegel verdeeld is. Daartoe werden aanvullende scanmetingen gedaan, zoals boven beschreven, maar bij een dophoogte van slechts $0,15 \mathrm{~m}$.

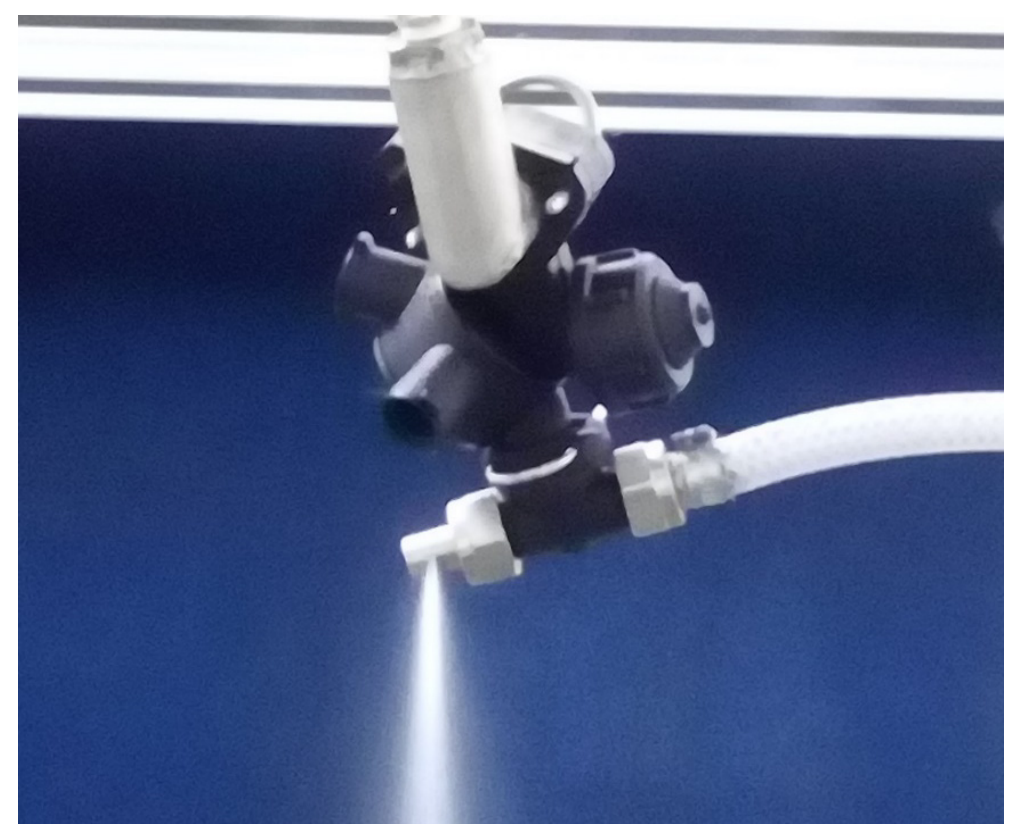

Figuur 3 Agrifac HTA 10/39 TKSS4 werd bij de druppelgroottemetingen onder een hoek geplaatst om de spuitnevel verticaal naar beneden te richten.

Voor de bepaling van het snelheidsverloop van druppels in de spuitkegel, zijn afzonderlijke metingen uitgevoerd met de PDPA. De puntmetingen zijn uitgevoerd in het centrum van elke spuitkegel op 4, 6, $9,12,15,20,25$ en $30 \mathrm{~cm}$ midden onder de dop. De meetresultaten bestonden uit de verticale snelheid en de diameter van elke gedetecteerde druppel. Hieruit werd de gemiddelde druppelsnelheid afgeleid als functie van druppelgrootte en afstand onder de dop. Deze resultaten werden vervolgens gebruikt om voor het IDEFICS driftmodel de entrainment te bepalen (de luchtstromingen in de spuitkegel) en de beginsnelheid van druppels bij het verlaten van de spuitdop.

De PDPA was tijdens de metingen als volgt ingesteld:

- Laservermogen in meetpunt $25 \mathrm{~mW}$

- Focus frontlens transmitter $1000 \mathrm{~mm}$

- Focus frontlens detector $1000 \mathrm{~mm}$

- Expander/contractor contractor

- Detectiehoek $40^{\circ}$

- Detectorspanning $540 \mathrm{~V}$

- Signaaldrempel $50 \mathrm{mV}$

- Meetbereik $5-1250 \mu \mathrm{m}$

- Diameter resolutie 2,4 $\mathrm{\mu m}$

- Probe Volume Correction ja 
Het laservermogen werd vooraf aan elke meting gecontroleerd en zo nodig bijgesteld. Ook de inkoppeling van de laserstralen in de glasvezels in de zogenaamde 'fiber-drive' werd voorafgaande aan elke meting gecontroleerd. Deze mechanische koppeling is zeer gevoelig voor temperatuurveranderingen en trillingen. Daarbij was steeds het nuttig laservermogen ter plaatse van de feitelijke meting leidend: dit vermogen werd constant gehouden op de genoemde waarde van $25 \mathrm{~mW}$.

De resultaten van de druppelgroottemetingen worden gepresenteerd als de $D_{v 10}, D_{v 50}, D_{v 90}, V_{100}$ en $\mathrm{V}_{\mathrm{gem}}$. Hieronder volgt een korte toelichting op deze begrippen:

- $\mathrm{D}_{\mathrm{v} 10}[\mu \mathrm{m}] ; 10 \%$ van het volume bestaat uit druppels die een diameter hebben die kleiner is dan de waarde van $\mathrm{D}_{\mathrm{V} 10}$;

- $\mathrm{D}_{\mathrm{V} 50}[\mu \mathrm{m}]=\mathrm{VMD}[\mu \mathrm{m}]$ (Volume Median Diameter); $50 \%$ van het volume bestaat uit druppels die een diameter hebben die kleiner is dan de waarde van $D_{\mathrm{V} 50}$;

- $D_{\text {v9o }}[\mu \mathrm{m}] ; 90 \%$ van het volume bestaat uit druppels die een diameter hebben die kleiner is dan de waarde van $\mathrm{D}_{\mathrm{v} 90}$;

- $\mathrm{V}_{100}[\%]$; volumepercentage van druppels met een diameter kleiner dan $100 \mu \mathrm{m}$;

- $v_{\text {gem }}[\mathrm{m} / \mathrm{s}]$; gemiddelde snelheid van alle gemeten druppels.

\subsection{Modelberekeningen}

De resultaten van de metingen van de druppelgrootteverdeling en de druppelsnelheden werden als invoer in het driftmodel IDEFICS-win (versie 0.434; maart 2020) gebruikt. Voor de

modelberekeningen met de HTA-doppen werd van de volgende veronderstellingen uitgegaan (er is daarbij aangegeven waar dat verschilt met de referentiesituatie met BCPC F/M doppen):

- afstand tussen doppen aan de spuitboom: $25 \mathrm{~cm}$ (voor BCPC F/M: dopafstand $50 \mathrm{~cm}$ );

- plaats van de laatste spuitdop 37,5 cm binnen het gewas * (voor BCPC F/M: $50 \mathrm{~cm}$ );

- een gewashoogte van $50 \mathrm{~cm}$;

- spuitboomhoogte $30 \mathrm{~cm}$ boven het gewas (voor BCPC F/M: $50 \mathrm{~cm}$ );

- rijsnelheid 1,67 m/s (=6,0 km/u);

- rijrichting evenwijdig aan de gewasrand;

- windrichting loodrecht op de gewasrand van het gewas af gericht;

- windsnelheid $3 \mathrm{~m} / \mathrm{s}$ (op $2 \mathrm{~m}$ hoogte);

- relatieve luchtvochtigheid $60 \%$;

- luchttemperatuur $15^{\circ} \mathrm{C}$;

- stabiliteit van de atmosfeer neutraal (geen thermiek).

* De uitgangssituatie was een gewas aardappelen met de laatste rug op $75 \mathrm{~cm}$ van de insteek van de sloot, bij een dopafstand van $50 \mathrm{~cm}$ staat de buitenste spuitdop op 12,5 cm buiten het midden van de laatste rug; gewasontwikkeling tot de insteek. Bij de berekeningen met IDEFICS is ter correctie van een aflopende gewasrand de afstand van de laatste dop tot de gewasrand afgerond op $50 \mathrm{~cm}$ (zie Figuur 4). Voor de HTA-doppen, met dopafstand $25 \mathrm{~cm}$, bevindt de buitenste dop zich op $25 \mathrm{~cm}$ buiten het midden van de laatste rug, dus op $37,5 \mathrm{~cm}$ vanaf de gewasrand.

De volvelds simulaties zijn in vijfvoud uitgevoerd, met 30.000 druppels per dop, voor 14 doppen verdeeld over een spuitbreedte van $50 \mathrm{~m}$. Door middel van interpolatie en extrapolatie voor niet gesimuleerde doppen is een simulatie van een volvelds bespuiting mogelijk. Ook de simulaties met de referentiedop zijn in vijfvoud uitgevoerd. Bij de HTA-doppen is een achterwaartse tilthoek ingesteld zoals voor de betreffende vloeistof-luchtdruk combinatie werd gemeten.

De resultaten van de modelberekeningen gaven de depositiewaarden op aaneensluitende strookjes van $25 \mathrm{~cm}$, gerekend vanaf de gewasrand. Deze resultaten werden bewerkt tot gemiddelde deposities op de strook 2,125-3,125 m vanaf de laatste spuitdop. Dit is de strook waarvoor bij de gekozen uitgangssituatie voor aardappelen het wateroppervlak van de sloot ligt (Huijsmans et al., 1997). 


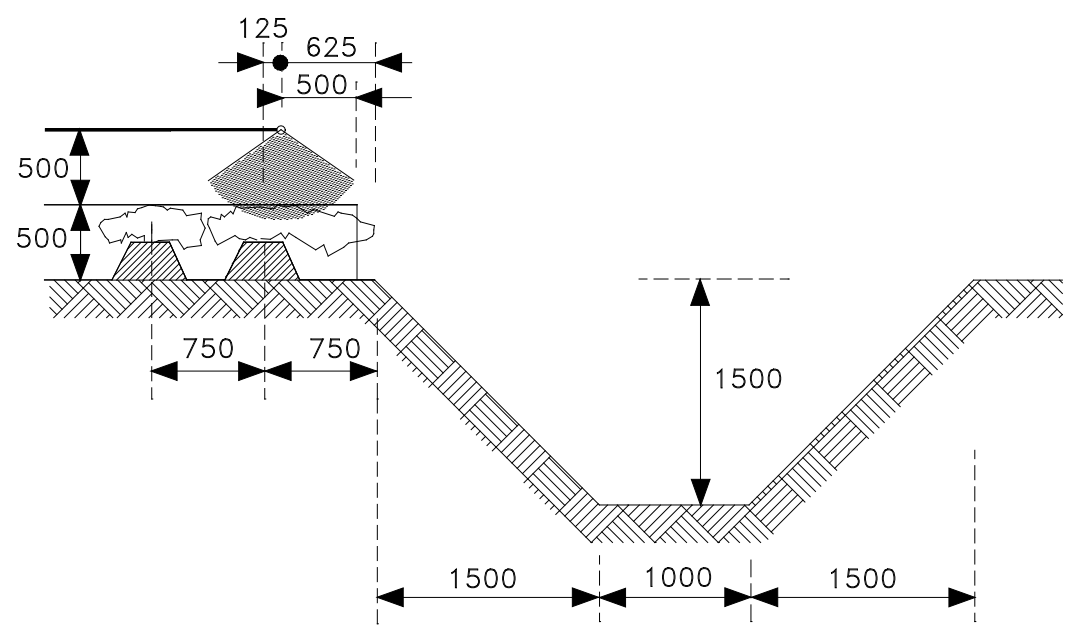

Figuur 4 Overzicht van de situatie voor de modelberekeningen bij een gewas aardappelen (afmetingen in $\mathrm{mm}$ ).

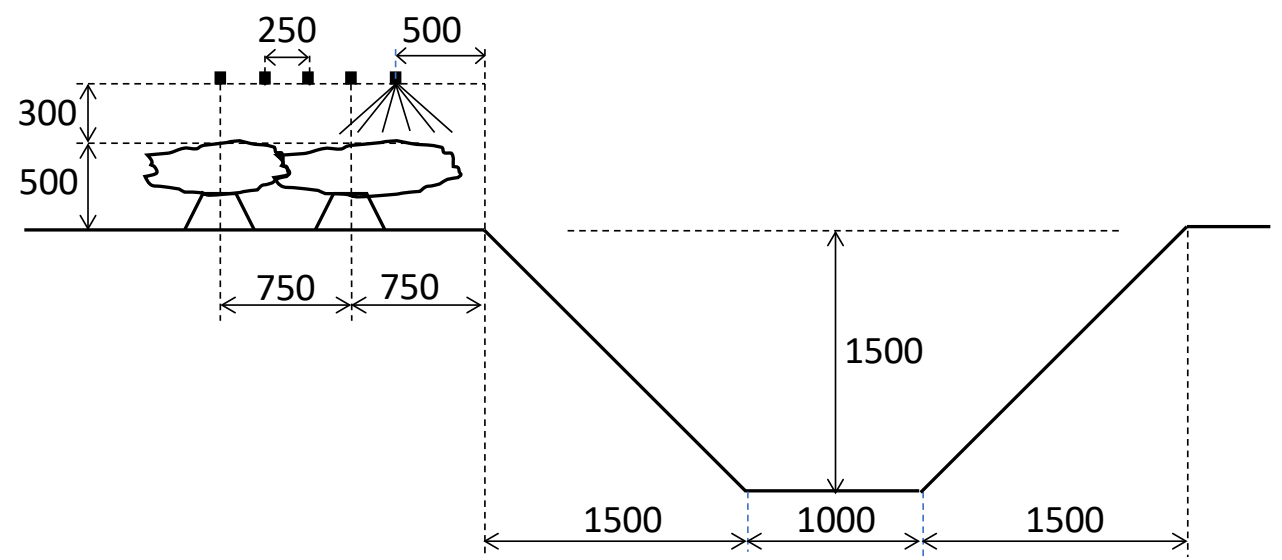

Figuur 5 Overzicht van de situatie voor de modelberekeningen bij een gewas aardappelen voor de situatie met verlaagde spuitboom en dopafstand $250 \mathrm{~mm}$ (afmetingen in $\mathrm{mm}$ ).

\subsection{Indeling in driftreductieklassen}

De driftreductie is berekend analoog aan de methode van Porskamp et al. (1999) ten opzichte van een referentiedop BCPC F/M en zoals weergegeven in het meetprotocol (I\&M, 2017b). Het referentiespectrum is op dezelfde dagen gemeten als waarop de druppelgroottemetingen van de onderzochte HTA-doppen zijn uitgevoerd.

$\mathrm{Er}$ is enige statistische spreiding te verwachten in zowel het gemiddelde druppelgroottespectrum (wat gevolgen heeft voor de berekende drift) als in de resultaten van de driftberekeningen op zich. De daaruit voortvloeiende variatiecoëfficiënt blijkt minder dan $3 \%$ te zijn. Bij de indeling van dopdrukcombinaties in driftreductieklassen is hiermee in deze rapportage geen rekening gehouden. Analoog aan de klassenindelingen in Duitsland (Ganzelmeier en Rautmann, 2000) en Engeland (Gilbert, 2000) en de beoordeling van resultaten van veldproeven (ISO-22369, 2006; I\&M, 2017c) is uitgegaan van de absolute waarden 50, 75, 90 en 95\% voor het vastleggen van de grenzen van de reductieklassen. 


\section{$3 \quad$ Meetresultaten}

\subsection{Spuitbordmetingen}

Op het spuitbord zijn de verdelingspatronen gemeten van 10 HTA-doppen met dopafstand 0,25 m en boomhoogte $0,30 \mathrm{~m}$ voor verschillende combinaties van vloeistof- en luchtdruk. Het spuitbord had gootjes van $2,5 \mathrm{~cm}$ breed. Voor de bepaling van de variatiecoëfficiënt (VC) zijn steeds 4 gootjes samengenomen om een effectieve gootbreedte van $10 \mathrm{~cm}$ te verkrijgen. De VC is berekend over een lengte van 1,00 $\mathrm{m}$ uit het midden van de vloeistofverdeling. De resultaten staan in Tabel 1.

Tijdens de metingen van de druppelspectra en de daaropvolgende simulaties met IDEFICS kwam naar voren dat andere combinaties van vloeistof- en luchtdruk mogelijk interessanter zouden kunnen zijn. Dat wil zeggen, in de zin dat een beter beeld van het effect van luchtdruk op drift en driftreductie gegeven zou kunnen worden, of dat de te verwachten driftreductie dichter bij een van de klassegrenzen (75\%, 90\%, 95\%) zou kunnen komen te liggen. Deze nieuwe combinaties zijn later toegevoegd en hun verdeling en VC is niet op het spuitbord bepaald; ze hebben dan de aanduiding '-' in de VC-kolom in Tabel 1. Overigens blijkt uit deze tabel dat de trend is dat naarmate de luchtdruk hoger is (bij een bepaalde vloeistofdruk), de VC afneemt tot een constante waarde van ca. $5 \%$. Het is daarom aannemelijk dat de niet bepaalde VC's alle ruim onder de norm van $10 \%$ vallen.

Uiteindelijk is een selectie gemaakt van drukcombinaties waarvoor druppelspectra en driftsimulaties zijn gedaan. Dit is in de laatste kolom van Tabel 1 aangegeven; zie verder in paragraaf 3.3.

Tabel 1 Geselecteerde combinaties van vloeistof- en luchtdruk voor HTA-doppen in deze studie.

\begin{tabular}{|c|c|c|c|}
\hline Vloeistofdruk [kPa] & Luchtdruk [kPa] & VC $[\%]^{1}$ & Metingen druppelgrootte ${ }^{2}$ \\
\hline \multirow[t]{7}{*}{200} & 20 & 18 & \\
\hline & 30 & 8.2 & $\mathrm{X}$ \\
\hline & 40 & 5.3 & \\
\hline & 50 & - & $x$ \\
\hline & 80 & - & $\mathrm{O}$ \\
\hline & 90 & - & $x$ \\
\hline & 100 & 5.2 & \\
\hline \multirow[t]{6}{*}{400} & 40 & 12 & \\
\hline & 60 & 4.6 & $\mathrm{O}$ \\
\hline & 80 & 4.4 & $x$ \\
\hline & 100 & 4.2 & $\mathrm{O}$ \\
\hline & 120 & 4.7 & $\mathrm{O}$ \\
\hline & 140 & - & $x$ \\
\hline \multirow[t]{4}{*}{600} & 60 & 17 & \\
\hline & 80 & 15 & \\
\hline & 90 & 4.8 & $x$ \\
\hline & 100 & 5.8 & $x$ \\
\hline
\end{tabular}

1 indien VC niet gemeten werd, staat '-' aangeduid; zie tekst.

2 druppelgroottemetingen: $\mathrm{X}$ : volledig (3 doppen, 3 herhalingen); O: indicatie (3doppen elk 1x gemeten). 


\subsection{Vloeistofafgifte}

Tien HTA-doppen werden genummerd en voor elk van deze doppen werd vervolgens de vloeistofafgifte gemeten bij vloeistofdruk van $300 \mathrm{kPa}$ en een luchtdruk van $60 \mathrm{kPa}$. De drie doppen met een afgifte het dichtst bij de mediaan werden geselecteerd voor de druppelgrootte spectrum metingen met de PDPA. De gemeten afgifte, mediaan en nummers van de drie geselecteerde doppen staan vermeld in Tabel 2. Afwijking in afgifte ten opzichte van de mediaan is een eigenschap van de individuele doppen en zal dus niet afhangen van welke drukken precies zijn ingesteld. Ter controle zijn ook afgiftemetingen gedaan bij $300 \mathrm{kPa}$ vloeistofdruk en $100 \mathrm{kPa}$ luchtdruk, en bij $350 \mathrm{kPa}$ vloeistofdruk en $110 \mathrm{kPa}$ luchtdruk. Uit deze drie bepalingen kwamen doppen 1, 4 en 8 naar voren als de doppen die het dichtst bij de mediaan kwamen wat betreft hun afgifte.

Tabel 2 Afgiftemetingen voor 10 HTA-doppen bij verschillende vloeistof- en luchtdrukken. In de laatste twee kolommen zijn de bijbehorende mediaan en de nummers van de drie geselecteerde doppen, waarvan de afgifte het dichtst bij de mediaan ligt, gegeven.

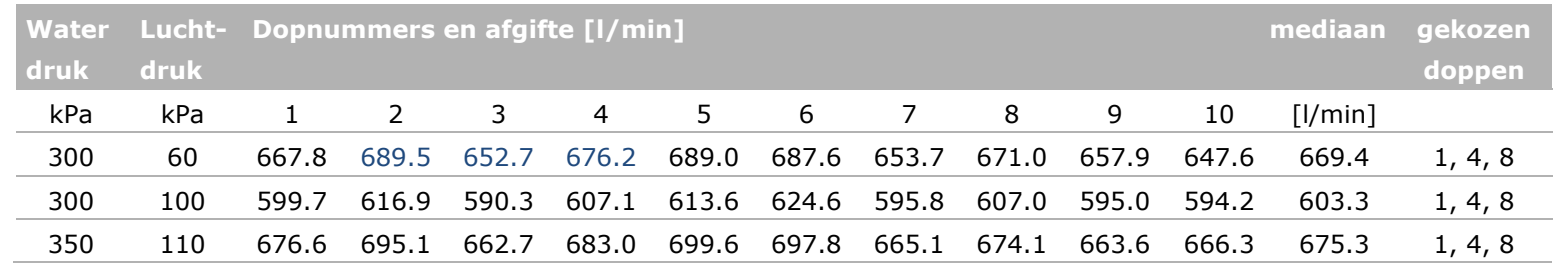

\subsection{Druppelgroottespectrum}

In Tabel 3 is het gemiddelde van de karakteristieke grootheden voor de HTA-doppen bij verschillende combinaties van vloeistof- en luchtdruk samengevat, zoals bepaald met de PDPA. De bijbehorende metingen van de BCPC F/M referentiedop zijn ook in deze tabel opgenomen. Voor de combinaties gemarkeerd met ' $X$ ' in Tabel 1 (zie paragraaf 3.1) werd van elk van de drie doppen de druppelgroottebepaling in drievoud uitgevoerd. Om een beter beeld te krijgen van het verband tussen vloeistofdruk, luchtdruk en driftreductie, zijn extra combinaties gemeten, gemarkeerd met ' $O$ ' in Tabel 1 . Deze combinaties zijn niet volledig uitgevoerd, maar van elk van de drie geselecteerde doppen is slechts 1 meting gedaan voor de druppelgrootteverdeling. De meetwaarden van de individuele metingen staan in Bijlage 1 (BCPC F/M en geselecteerde combinaties) en Bijlage 2 (extra combinaties).

$\mathrm{Er}$ is voor de bespuiting van de perceelrand besloten de HTA-doppen ook als randmodus-dop te plaatsen op het einde van de spuitboom, waarbij de luchtdruk op 0 ingesteld zou worden, om een zo grof mogelijk spuitbeeld te verkrijgen. De metingen hiervoor omvatten 3 doppen elk in tweevoud gemeten. De gemiddelde karakteristieken hiervan zijn ook in Tabel 3 opgenomen. De individuele metingen staan in Bijlage 2 vermeld.

Bij 200 kPa waterdruk zonder luchtdruk, was het gemiddelde aantal druppels per meting slechts 3100 . Deze combinatie van waterdruk en luchtdruk produceerde zo weinig druppels, dat het niet mogelijk was binnen acceptabele meettijd een aantal van 10000 druppels te verkrijgen. Echter, omdat deze dopdrukcombinatie alleen op de buitenste doppositie gebruikt wordt en niet voor de hele spuitboom, is het effect van een licht verhoogde onnauwkeurigheid op het totale driftbeeld zeer gering. Daarbij is de $\mathrm{V}_{100}$ (die in hoge mate bepalend is voor de hoogte van driftdepositie) van deze dopdrukcombinatie zeer laag $(0,06 \%)$. Een licht verhoogde relatieve fout zal daarom niet leiden tot een significant verhoogde absolute fout in driftdeposities. 
Tabel 3 Samenvatting van de karakteristieke grootheden van het druppelgroottespectrum, gemiddelde druppelsnelheid en aantal gemeten druppels voor de HTA-doppen bij verschillende combinaties van vloeistof- en luchtdruk en voor de BCPC F/M. Gemeten met PDPA.

\begin{tabular}{|c|c|c|c|c|c|c|c|c|c|}
\hline $\begin{array}{c}\text { Vloeistofdruk } \\
\text { [kPa] }\end{array}$ & $\begin{array}{l}\text { Luchtdruk } \\
\text { [kPa] }\end{array}$ & $\begin{array}{c}\text { Dv10 } \\
{[\mu \mathrm{m}]}\end{array}$ & $\begin{array}{l}\text { Dvso } \\
\text { [ } \mu \mathrm{m}]\end{array}$ & $\begin{array}{l}\text { Dvgo } \\
{[\mu \mathrm{m}]}\end{array}$ & $\begin{array}{l}V_{100} \\
{[\%]}\end{array}$ & $\begin{array}{c}\text { Vgem } \\
{[\mathrm{m} / \mathrm{s}]}\end{array}$ & $\begin{array}{c}\text { Tophoek } \\
{\left[^{\circ}\right]}\end{array}$ & $\begin{array}{l}\text { Tilthoek } \\
{\left[{ }^{\circ}\right]}\end{array}$ & $\begin{array}{c}\text { Gem. } \\
\text { aantal } \\
\text { druppels }\end{array}$ \\
\hline \multicolumn{10}{|l|}{ BCPC F/M: } \\
\hline 300 & - & 116 & 219 & 357 & 6.40 & 3.50 & 110 & 0 & 38900 \\
\hline \multicolumn{10}{|c|}{ HTA 10/39 TKSS4: } \\
\hline \multirow[t]{7}{*}{200} & 30 & 316 & 690 & 1203 & 0.40 & 1.47 & 104 & 11 & 10600 \\
\hline & 35 & 285 & 614 & 1106 & 0.52 & 1.56 & 107 & 10 & 14100 \\
\hline & 50 & 220 & 485 & 890 & 0.93 & 1.78 & 112 & 10 & 14900 \\
\hline & 60 & 184 & 422 & 768 & 1.48 & 1.90 & 110 & 10 & 13300 \\
\hline & 80 & 150 & 342 & 664 & 2.75 & 2.08 & 105 & 10 & 21000 \\
\hline & 90 & 136 & 307 & 577 & 4.00 & 2.14 & 104 & 9 & 26500 \\
\hline & 0 & 625 & 1131 & 1560 & 0.06 & 1.55 & 90 & 14 & 3100 \\
\hline \multirow[t]{8}{*}{400} & 45 & 339 & 740 & 1227 & 0.27 & 1.97 & 105 & 10 & 13600 \\
\hline & 55 & 279 & 613 & 1071 & 0.44 & 1.98 & 109 & 10 & 22700 \\
\hline & 60 & 267 & 577 & 1001 & 0.52 & 2.03 & 112 & 10 & 10100 \\
\hline & 80 & 205 & 440 & 808 & 0.97 & 2.28 & 114 & 9 & 28300 \\
\hline & 100 & 176 & 378 & 683 & 1.60 & 2.56 & 114 & 9 & 14300 \\
\hline & 120 & 151 & 324 & 588 & 2.66 & 2.69 & 112 & 10 & 19500 \\
\hline & 140 & 139 & 297 & 540 & 3.56 & 2.83 & 106 & 9 & 25000 \\
\hline & 0 & 383 & 848 & 1393 & 0.28 & 1.69 & 102 & 12 & 13500 \\
\hline \multirow[t]{6}{*}{600} & 90 & 235 & 498 & 880 & 0.63 & 2.52 & 110 & 11 & 22400 \\
\hline & 100 & 210 & 443 & 804 & 0.92 & 2.63 & 114 & 12 & 26800 \\
\hline & 120 & 179 & 381 & 693 & 1.45 & 2.75 & 117 & 8 & 17800 \\
\hline & 150 & 153 & 322 & 572 & 2.46 & 3.00 & 115 & 8 & 24800 \\
\hline & 200 & 128 & 267 & 494 & 4.63 & 3.34 & 107 & 8 & 27200 \\
\hline & 0 & 262 & 646 & 1263 & 0.75 & 1.74 & 110 & 11 & 25600 \\
\hline
\end{tabular}

\subsection{Modelberekeningen IDEFICS}

Met het driftmodel IDEFICS zijn volvelds berekeningen uitgevoerd voor de gekozen situaties van vloeistof- en luchtdrukcombinaties. Bij een boom die volledig is uitgerust met gelijk doppen (met dopafstand $0,25 \mathrm{~m}$ ), zal de buitenste dop zich op 0,375 $\mathrm{m}$ vanaf de gewasrand bevinden (zie paragraaf 2.3). In de gekozen situatie met een randmodus-dop werden in de simulaties de twee buitenste doppen (dop 1 en 2) dicht gezet, waarbij de HTA-randmodus-dop geplaatst werd tussen deze twee buitenste doppen in op 0,10 m vanaf dop 1 en dus 0,15 m vanaf dop 2. De HTArandmodus-dop had dezelfde vloeistofdruk als de overige doppen aan de spuitboom, maar dan zonder luchtdruk. De randmodus-dop werd $8^{\circ}$ gekanteld van de gewasrand af.

De simulaties zijn in vijfvoud uitgevoerd, waarna hiervoor het gemiddelde en de standaarddeviatie van de driftdepositie op de evaluatiestrook werd bepaald. Deze waarden staan in Tabel 4 vermeld. De kolom driftverhouding geeft de verhouding luchtdruk/vloeistofdruk aan. De gemiddelde driftreductie op die strook is bepaald ten opzichte van de driftdepositie voor een referentiebespuiting met BCPC$\mathrm{F} / \mathrm{M}$ doppen. Ten slotte is de indeling in driftreductieklassen op grond van deze driftreducties in de tabel opgenomen. De standaarddeviaties in de simulaties zijn erg klein, waarmee de toevallige fout in de driftreducties ook klein is; $0,1 \%$ voor de hoogste driftreducties, oplopend tot $0,8 \%$ voor de laagste driftreducties in de tabel. 
Tabel 4 Berekende driftdepositie en driftreducties op de strook 2,000-3,000 vanaf de laatste spuitdop ${ }^{1}$ voor de HTA-doppen bij verschillende combinaties van vloeistof- en luchtdruk en voor de BCPC F/M; met bijbehorende indeling driftreductieklassen.

\begin{tabular}{|c|c|c|c|c|c|c|c|c|}
\hline \multirow{2}{*}{$\begin{array}{l}\text { Vloeistofidruk } \\
\text { [kPa] } \\
\text { BCPC F/M: }\end{array}$} & \multirow{2}{*}{$\begin{array}{l}\text { Luchtdruk } \\
\text { [kPa] }{ }^{2}\end{array}$} & \multirow{2}{*}{$\begin{array}{l}\text { Druk- } \\
\text { verhouding }\end{array}$} & \multirow{2}{*}{$\begin{array}{c}\text { Drift } \\
\text { [\%dosering] }\end{array}$} & \multirow{2}{*}{$\begin{array}{l}\text { Stand.Dev. } \\
\text { [\%dosering] }\end{array}$} & \multirow{2}{*}{$\begin{array}{c}\text { Reductie } \\
{[\%]}\end{array}$} & \multicolumn{3}{|c|}{ Driftreductieklasse } \\
\hline & & & & & & $75 \%$ & $90 \%$ & $95 \%$ \\
\hline 300 & - & & $2.534^{3}$ & 0.058 & - & & & \\
\hline \multicolumn{9}{|c|}{ HTA 10/39 TKSS4: } \\
\hline \multirow[t]{6}{*}{200} & 30 & 0.15 & 0.116 & 0.003 & 95.4 & & & $x$ \\
\hline & 35 & 0.18 & 0.148 & 0.004 & 94.2 & & $x$ & \\
\hline & 50 & 0.25 & 0.248 & 0.005 & 90.2 & & $x$ & \\
\hline & $60 *$ & 0.30 & 0.338 & 0.006 & 86.7 & $x$ & & \\
\hline & $80 *$ & 0.40 & 0.502 & 0.017 & 80.2 & $x$ & & \\
\hline & 90 & 0.45 & 0.655 & 0.015 & 74.2 & & & \\
\hline \multirow[t]{7}{*}{400} & 45 & 0.11 & 0.094 & 0.002 & 96.3 & & & $x$ \\
\hline & 55 & 0.14 & 0.140 & 0.004 & 94.5 & & $x$ & \\
\hline & $60 *$ & 0.15 & 0.157 & 0.003 & 93.8 & & $x$ & \\
\hline & 80 & 0.20 & 0.250 & 0.009 & 90.1 & & $x$ & \\
\hline & $100 *$ & 0.25 & 0.343 & 0.007 & 86.5 & $x$ & & \\
\hline & $120 *$ & 0.30 & 0.479 & 0.014 & 81.1 & $x$ & & \\
\hline & 140 & 0.35 & 0.567 & 0.016 & 77.6 & $x$ & & \\
\hline \multirow[t]{5}{*}{600} & 90 & 0.15 & 0.189 & 0.005 & 92.5 & & $x$ & \\
\hline & 100 & 0.17 & 0.251 & 0.012 & 90.1 & & $x$ & \\
\hline & $120 *$ & 0.20 & 0.341 & 0.006 & 86.6 & $x$ & & \\
\hline & $150 *$ & 0.25 & 0.457 & 0.015 & 81.9 & $x$ & & \\
\hline & 200 & 0.33 & 0.687 & 0.011 & 72.9 & & & \\
\hline
\end{tabular}

1 indien de spuitboom volledig met gelijk doppen zou zijn uitgevoerd (zonder kantdop), bij dopafstand 0,25.

2 de extra combinaties zijn met een * gemarkeerd, ze wegen minder zwaar mee in de bepaling van de curves van Figuur 6.

3 in de referentiesituatie (BCPC F/M) bij 0,50 m dopafstand ligt de evaluatiestrook 2,125-3,125 vanaf de buitenste dop, omdat de buitenste dop

$0,125 \mathrm{~m}$ verder windopwaarts geplaatst is.

De driftreducties uit Tabel 4 zijn in een grafiek uitgezet tegen de drukverhouding, Figuur 6. De open vierkante symbolen zijn de extra combinaties, waarvoor minder metingen (3 in plaats van 9) zijn gedaan van de druppelgroottes. De getrokken lijnen zijn gefit op alle punten, maar de extra combinaties telden daarbij maar voor $1 / 3$ mee, overeenkomstig de verhouding van het aantal metingen van de druppelgrootteverdelingen. Voor de simulaties bij $600 \mathrm{kPa}$ vloeistofdruk paste een lineair verband uitstekend. Bij 200 en 400 kPa werd gefit met een kwadratische vergelijking. De wiskundige vergelijkingen zijn aan de grafiek toegevoegd.

Op basis van de gefitte curves zijn de exacte drukverhoudingen bepaald waarvoor de klassengrenzen $75 \%$, 90\% en $95 \%$ worden gekruist. Deze waarden en de daaruit bepaalde absolute luchtdrukken staan in Tabel 5. Dus voor de in Tabel 5 genoemde combinaties van vloeistofdruk en luchtdruk bereikt de driftreductie precies een van die klassengrenzen, voor een bespuiting met HTA-doppen bij genoemde drukken en een HTA-randmodus-dop, met verder de boomhoogte en dopposities zoals eerder vermeld. Weliswaar is ook voor de lineaire curve bij $600 \mathrm{kPa}$ zo'n drukcombinatie te bepalen voor het $95 \%$ kruispunt, maar de ligging hiervan kon niet met zekerheid vastgesteld worden.

De gemiddelde afwijking van de meetpunten ten opzichte van de gefitte curves in Figuur 6 bedraagt $0,3 \%$ in de driftreducties. Dit betreft een toevallige fout op 5 tot 7 meetpunten (het aantal meetpunten verschilt voor de diverse waterdrukken). Dit betekent dat de gefitte curves een factor $1 / \sqrt{ } 5$ tot $1 / \sqrt{ } 7$ nauwkeuriger zijn dan de individuele meetpunten. Ofwel, met behulp van de gefitte curves in Figuur 6 zijn driftreducties op ca. 0,1\% nauwkeurig te schatten. 


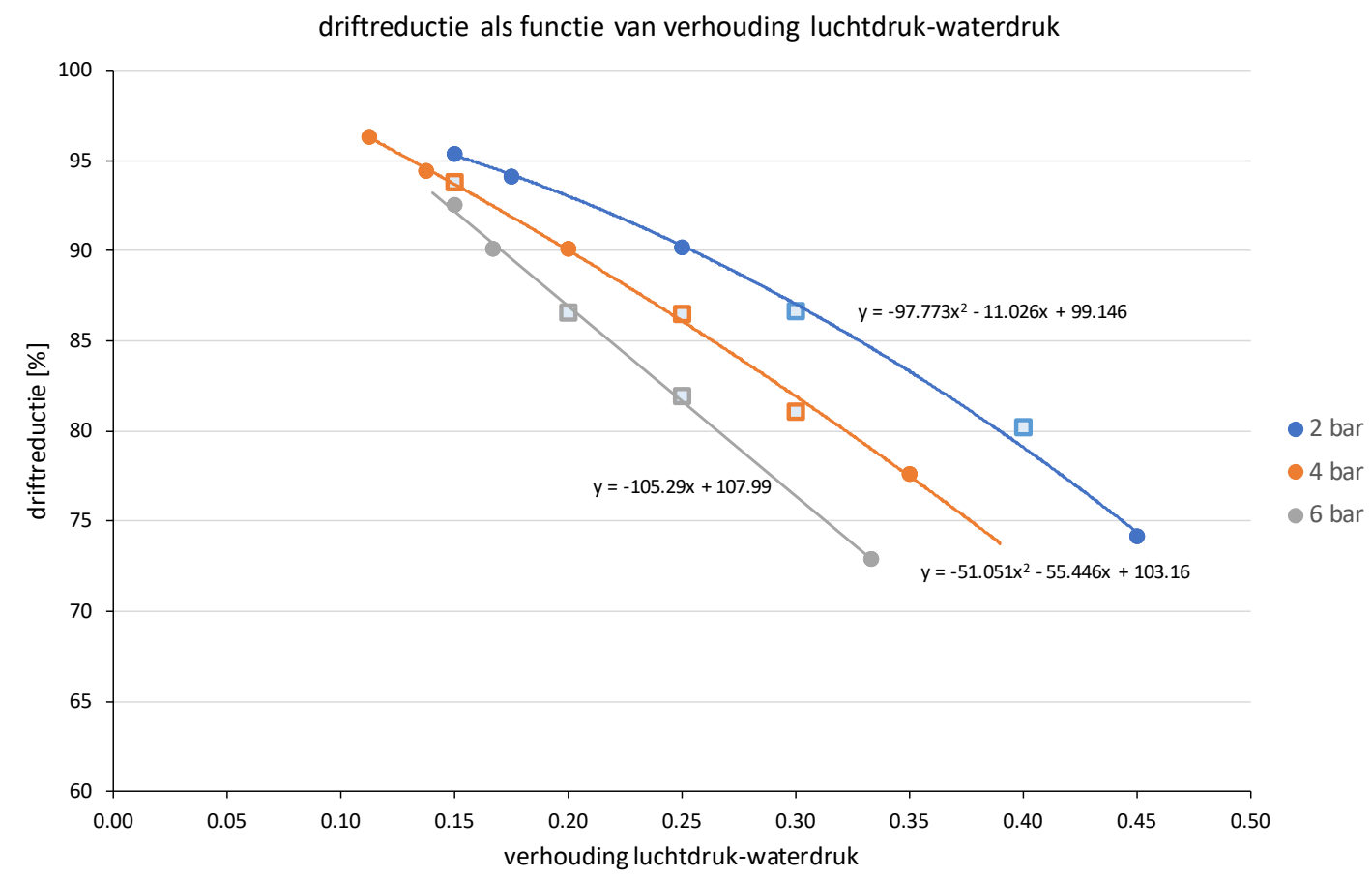

Figuur 6 Driftreductie op de evaluatiestrook als functie van de verhouding tussen luchtdruk en vloeistofdruk, gerangschikt voor de drie vloeistofdrukken. Voor spuitboom met HTA-doppen, waarbij buitenste twee doppen vervangen zijn door een HTA-randmodus-dop zoals in de tekst beschreven. Dichte ronde symbolen: geselecteerde combinaties; open vierkante symbolen: extra combinaties.

Tabel 5 Berekende drukverhouding op de kruisingen van gefitte curves met klassegrenzen 75\%, $90 \%$ en $95 \%$ voor de verschillende vloeistofdrukken bij de simulaties met HTA-doppen; met hieruit bepaalde luchtdrukken.

\begin{tabular}{|c|c|c|c|c|c|c|}
\hline \multirow[t]{2}{*}{$\begin{array}{c}\text { Vloeistofdruk } \\
\text { [kPa] }\end{array}$} & \multicolumn{3}{|c|}{ Drukverhouding } & \multicolumn{3}{|c|}{$\begin{array}{l}\text { Luchtdruk } \\
\text { [kPa] }\end{array}$} \\
\hline & $75 \%$ & $90 \%$ & $95 \%$ & $75 \%$ & $90 \%$ & $95 \%$ \\
\hline 400 & 0.375 & 0.200 & 0.132 & 150 & 80 & 53 \\
\hline 600 & 0.314 & 0.171 & 1 & 188 & 102 & 1 \\
\hline
\end{tabular}

1 het snijpunt met $95 \%$ driftreductie bij $600 \mathrm{kPa}$ vloeistofdruk is niet bepaald.

De gevonden drukcombinaties in Tabel 5 zijn in Figuur 7 als grafiek te zien. De lijnen geven het globale verloop van drukcombinaties bij een constante driftreductie. In principe geven de lijnen een verzameling van drukcombinaties waarvoor een van de klassengrenzen $75 \%$, 90\% of $95 \%$ wordt behaald.

De curves van gelijke driftreductie in Figuur 7 kunnen gebruikt worden om bij andere (nog niet gemeten) vloeistofdrukken te schatten welke luchtdruk nodig is om een bepaalde driftreductie te verkrijgen. Als voorbeeld is dit voor een vloeistofdruk van 300 en 500 kPa bepaald, zie Tabel 6. Voor de volledigheid staan hierin ook de luchtdrukken uit Tabel 5 in voor de vloeistofdrukken 200, 400 en $600 \mathrm{kPa}$. In praktijk zal het moeilijk zijn om de luchtdrukken precies op de in de tabel genoemde waarden in te stellen. Stel dat de luchtdruk op $5 \mathrm{kPa}$ ingesteld kan worden, dan is voor alle luchtdrukken de op $5 \mathrm{kPa}$ naar beneden afgeronde waarde de beste keuze. De op deze wijze afgeronde waarden staan ook vermeld in Tabel 6.

Hierboven is genoemd dat de nauwkeurigheid van geschatte driftreducties ca. 0,1\% bedraagt. Een dergelijk kleine variatie in driftreductie zou in alle onderzochte gevallen al gerealiseerd worden door ca. 0,6 kPa variatie in luchtdruk; in sommige gevallen is zelfs minder dan 0,6 kPa nodig. De fout van de in Tabel 6 berekende en geschatte luchtdrukken (linker 3 kolommen) is kleiner dan 0,6 kPa en zijn daarmee voldoende nauwkeurig en betrouwbaar. 


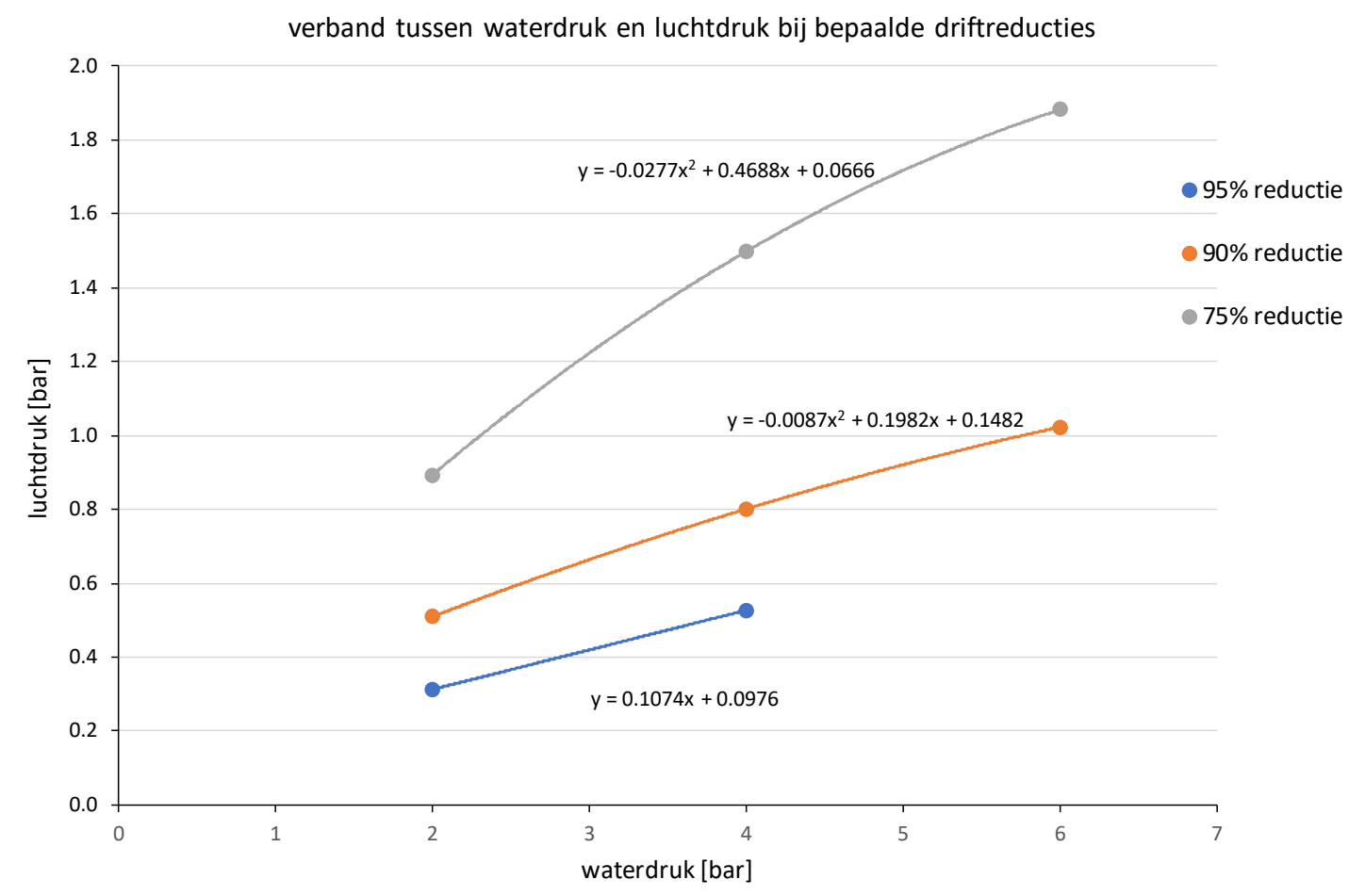

Figuur 7 Berekende combinaties van vloeistof- en luchtdruk waarbij de driftreducties exact 75\%, $90 \%$ of $95 \%$ bedragen. Gefitte curves geven het globale verloop aan.

Tabel 6 Berekende en geschatte luchtdrukken op de kruisingen van gefitte curves met klassegrenzen 75\%, 90\% en 95\% voor de verschillende vloeistofdrukken bij de simulaties met HTAdoppen. Afgeronde luchtdruk is naar beneden afgerond op $5 \mathrm{kPa}$.

\begin{tabular}{|c|c|c|c|c|c|c|}
\hline \multirow[t]{2}{*}{$\begin{array}{c}\text { Vloeistofdruk } \\
{[\mathrm{kPa}]}\end{array}$} & \multicolumn{3}{|c|}{$\begin{array}{l}\text { Luchtdruk } \\
\text { [kPa] }\end{array}$} & \multicolumn{3}{|c|}{$\begin{array}{l}\text { Afgeronde luchtdruk } \\
\text { [kPa] }\end{array}$} \\
\hline & $75 \%$ & $90 \%$ & $95 \%$ & $75 \%$ & $90 \%$ & $95 \%$ \\
\hline 200 & 89 & 51 & 31 & 85 & 50 & 30 \\
\hline $300^{2}$ & 122 & 66 & 42 & 120 & 65 & 40 \\
\hline 400 & 150 & 80 & 53 & 150 & 80 & 50 \\
\hline $500^{2}$ & 172 & 92 & 1 & 170 & 90 & 1 \\
\hline 600 & 188 & 102 & 1 & 185 & 100 & 1 \\
\hline
\end{tabular}

1 het snijpunt met $95 \%$ reductie bij deze vloeistofdruk is niet bepaald.

2 luchtdrukken bij deze vloeistofdrukken zijn geschat uit gefitte curves. 


\section{Discussie}

Met de lucht-vloeistofdoppen HTA 10/39 TKSS4 zijn door variatie van vloeistofdruk en luchtdruk de druppelgrootteverdeling en vloeistofafgifte min of meer onafhankelijk van elkaar in te stellen. Door het meten van de druppelgrootteverdeling van een groot aantal drukcombinaties en vervolgens met het driftmodel IDEFICS simulaties uit te voeren, is een generiek model te vormen van mogelijke drukcombinaties om een zekere driftreductie te bereiken. Driftdepositie en driftreducties zijn vooralsnog alleen bepaald bij een spuitboomhoogte van 0,30 m en dopafstand van 0,25 m. Bovendien is de HTA-dop zonder luchttoevoer als randmodus-dop gebruikt. Voor andere keuzes wat betreft boomhoogte of plaatsing van doppen aan de spuitboom, biedt het generieke model uit deze studie geen oplossing.

Een punt van aandacht is de variatiecoëfficiënt van de vloeistofverdeling onder de spuitboom bij $95 \%$ driftreductie met een vloeistofdruk groter dan $400 \mathrm{kPa}$. Uit het generieke model, zoals bijvoorbeeld gepresenteerd in Figuur 7, zou weliswaar de driftreductie goed in te schatten zijn, maar niet of de VC aan de eis van minder dan $10 \%$ voldoet. Dat zal toch nader onderzocht moeten worden. Wanneer het mogelijk zou zijn om in Figuur 7 tevens grenslijnen aan te geven waarbinnen de VC kleiner dan $10 \%$ is, dan kan direct worden gezien of bepaalde combinaties toegestaan zijn of niet. 


\section{$5 \quad$ Conclusie}

Met de lucht-vloeistofdoppen HTA 10/39 TKSS4 zijn door variatie van vloeistofdruk en luchtdruk de druppelgrootteverdeling en vloeistofafgifte min of meer onafhankelijk van elkaar in te stellen. In deze studie is voor dit systeem, genaamd HTA DriftControlPlus, een groot aantal drukcombinaties door meting en simulaties onderzocht wat betreft driftdepositie en driftreducties op een standaardsloot, bij een spuitboomhoogte van 0,30 m en dopafstand van 0,25 m. De verscheidenheid aan drukcombinaties kan gebruikt worden voor een generiek model om bij niet gemeten drukcombinaties toch een goede schatting te maken van driftdepositie en driftreductie. Wel moet geverifieerd worden of de variatiecoëfficiënt van de vloeistofverdeling onder de spuitboom niet de $10 \%$ zal overschrijden. Dit laatste is vooral van belang bij relatief lage luchtdrukken en daaraan gekoppelde hogere driftreducties.

In deze studie zijn vloeistofdrukken van 200, 400 en $600 \mathrm{kPa}$ toegepast. Het verdient aanbeveling om ook bij enkele combinaties met 300 of $500 \mathrm{kPa}$ vloeistofdruk metingen en simulaties te doen, ter onderbouwing en verificatie van het generieke model.

Het instellen van de juiste luchtdruk blijft een kritisch punt. Zeker bij relatief lage luchtdrukken, waar een verschil van $5 \mathrm{kPa}$ al direct een verschil in driftreductie kan betekenen. 


\section{Literatuur}

Ganzelmeier, H. \& Rautmann D., 2000. Drift, drift reducing sprayers and sprayer testing. Aspects of Applied Biology 57, Pesticide application, 2000, p1-10.

Gilbert, A.J., 2000. Local Environmental Risk Assessment for Pesticides (LERAP) in the UK. Aspects of Applied Biology 57, Pesticide Application, 2000, p83-90.

Holterman, H.J., J.C. van de Zande, H.A.J. Porskamp en J.F.M. Huijsmans, 1997. Modelling spray drift from boom sprayers. Computers and Electronics in Agriculture 19(1997): p1-22.

Huijsmans, J.F.M., H.A.J. Porskamp en J.C. van de Zande, 1997. Drift(beperking) bij de toediening van gewasbeschermingsmiddelen. Evaluatie van de drift van spuitvloeistof bij bespuitingen in de fruitteelt, de volveldsteelten en de boomteelt (stand van zaken december 1996). IMAG-DLO Rapport 97-04, IMAG, Wageningen, 38 pp.

I\&M, 2012. Activiteitenbesluit Milieubeheer, Staatsblad 2012 441/643

I\&M, 2017a. Wijziging van het Activiteitenbesluit milieubeheer in verband met de vermindering van emissies van gewasbeschermingsmiddelen in de glastuinbouw en open teelten. Staatsblad 23 juni 2017. 305

I\&M, 2017b. Meetprotocol voor het vaststellen van de driftreductie van spuitdoppen voor neerwaartse en op- en zijwaartse bespuiting - versie 1 juli 2017. Op Helpdeskwater.nl.

I\&M, 2017c. Meetprotocol voor het vaststellen van de driftreductie van neerwaartse en op- en zijwaartse spuittechnieken - versie 1 juli 2017. Op Helpdeskwater.nl.

ISO 16119-2, 2013. Agricultural and forestry machinery - Environmental requirements for sprayers - Part 2: Horizontal boom sprayers. International Organization for Standardization, Geneva.

ISO 16122-2, 2015. Agricultural and forestry machinery - Inspection of sprayers in use - Part 2: Horizontal boom sprayers. International Organization for Standardization, Geneva.

ISO-22369, 2006. Crop protection equipment - Drift classification of spraying equipment. Part 1. Classes. International Organization for Standardization, Geneva.

ISO 5682-1, 2014. Equipment for crop protection - Spraying equipment - Part 1: Test methods for sprayer nozzles. International Organization for Standardization, Geneva.

ISO5682-2, 2017. Equipment for crop protection - Spraying equipment - Part 2: Test methods to assess the horizontal transverse distribution for hydraulic sprayers. International Organization for Standardization, Geneva.

Porskamp, H.A.J., J.C. van de Zande, H.J. Holterman en J.F.M. Huijsmans, 1999. Opzet van een classificatiesysteem voor spuitdoppen op basis van driftgevoeligheid. IMAG-DLO Rapport 99-02, IMAG, Wageningen, $22 \mathrm{pp}$.

Southcombe, E.S.E., P.C.H. Miller, H. Ganzelmeier, J.C. van de Zande, A. Miralles \& A.J. Hewitt, 1997. The international (BCPC) spray classification system including a drift potential factor. Proceedings of the Brighton Crop Protection Conference - Weeds, 1997. November 1997. Brighton. UK. p.371-380.

TCT, 2017. Beoordelingssystematiek emissiereducerende maatregelen open teelt. Op Helpdeskwater.nl.

TCT, 2019. Lijst met indeling van spuitdoppen in Driftreducerende Dop-klassen (DRD-lijst). Op Helpdeskwater.nl. 


\section{Bijlage 1 Overzicht metingen van druppelgroottes}

In Tabel B. 1 is een overzicht gegeven van druppelgroottemetingen voor de referentiedop BCPC F/M, zoals uitgevoerd op de dagen waarop ook de HTA-doppen werden gemeten. Deze 30 referentiemetingen zijn samengevoegd tot het druppelgroottespectrum voor de BCPC F/M referentiedop om te gebruiken in de IDEFICS simulaties.

De Tabellen B.2-B.4 geven een overzicht van de druppelgroottemetingen voor de HTA-doppen bij de geselecteerde combinaties van vloeistofdruk en luchtdruk. Metingen werden voor drie doppen in drievoud uitgevoerd.

Tabel B.1 Overzicht van de karakteristieke grootheden van het druppelgroottespectrum, gemiddelde druppelsnelheid en aantal gemeten druppels voor de BCPC-F/M referentiedop bij $300 \mathrm{kPa}$ vloeistofdruk; gemeten met PDPA gedurende de dagen dat ook HTA-doppen werden gemeten.

\begin{tabular}{|c|c|c|c|c|c|c|c|}
\hline Run & Datum & $\begin{array}{c}\text { Dv10 } \\
{[\mu \mathrm{m}]}\end{array}$ & $\begin{array}{c}\text { Dv50 } \\
{[\mu \mathrm{m}]}\end{array}$ & 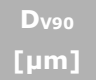 & $\begin{array}{l}V_{100} \\
{[\%]}\end{array}$ & $\begin{array}{c}V_{\mathrm{gem}} \\
{[\mathrm{m} / \mathrm{s}]}\end{array}$ & $\begin{array}{c}\text { Aantal } \\
\text { druppels }\end{array}$ \\
\hline 1 & $27-2-2020$ & 114.9 & 220.8 & 356.9 & 6.35 & 3.64 & 37800 \\
\hline 2 & & 112.8 & 217.7 & 364.7 & 6.77 & 3.47 & 41200 \\
\hline 3 & & 117.4 & 220.3 & 349.1 & 5.90 & 3.60 & 36900 \\
\hline 4 & & 116.7 & 218.7 & 354.9 & 5.93 & 3.67 & 36100 \\
\hline 5 & & 113.8 & 217.3 & 348.6 & 6.59 & 3.57 & 37100 \\
\hline 6 & $28-2-2020$ & 113.2 & 218.3 & 353.6 & 6.61 & 3.52 & 37800 \\
\hline 7 & & 115.1 & 219.5 & 365.0 & 6.36 & 3.50 & 39000 \\
\hline 8 & $2-3-2020$ & 117.4 & 220.5 & 359.4 & 5.87 & 3.59 & 35900 \\
\hline 9 & & 112.1 & 215.6 & 353.8 & 6.75 & 3.51 & 39600 \\
\hline 10 & $3-3-2020$ & 113.5 & 219.9 & 379.6 & 6.51 & 3.51 & 36300 \\
\hline 11 & & 113.5 & 218.3 & 365.1 & 6.54 & 3.71 & 37500 \\
\hline 12 & & 114.4 & 214.6 & 344.2 & 6.29 & 3.61 & 36600 \\
\hline 13 & $6-3-2020$ & 116.2 & 220.1 & 348.9 & 6.07 & 3.50 & 37400 \\
\hline 14 & & 113.1 & 215.8 & 354.6 & 6.71 & 3.50 & 40500 \\
\hline 15 & & 113.4 & 215.1 & 356.9 & 6.58 & 3.44 & 40100 \\
\hline 16 & $9-3-2020$ & 112.2 & 214.8 & 342.6 & 6.78 & 3.44 & 41300 \\
\hline 17 & & 113.8 & 216.7 & 358.2 & 6.47 & 3.48 & 40200 \\
\hline 18 & & 116.3 & 218.9 & 349.2 & 6.05 & 3.48 & 38300 \\
\hline 19 & $10-3-2020$ & 112.6 & 217.0 & 354.9 & 6.64 & 3.49 & 39300 \\
\hline 20 & & 114.6 & 217.4 & 356.5 & 6.31 & 3.45 & 39400 \\
\hline 21 & & 111.8 & 215.8 & 359.6 & 6.95 & 3.49 & 42900 \\
\hline 22 & & 114.8 & 218.1 & 358.2 & 6.34 & 3.45 & 39900 \\
\hline 23 & $11-3-2020$ & 113.8 & 218.3 & 364.3 & 6.52 & 3.38 & 41100 \\
\hline 24 & & 114.9 & 218.7 & 357.6 & 6.29 & 3.50 & 39900 \\
\hline 25 & & 115.7 & 216.9 & 351.7 & 6.01 & 3.37 & 38100 \\
\hline 26 & $12-3-2020$ & 117.7 & 218.2 & 350.3 & 5.76 & 3.52 & 37000 \\
\hline 27 & & 116.2 & 218.3 & 370.1 & 6.07 & 3.46 & 38400 \\
\hline 28 & & 114.2 & 218.0 & 357.3 & 6.44 & 3.42 & 40100 \\
\hline 29 & $13-3-2020$ & 112.3 & 214.7 & 346.9 & 6.81 & 3.34 & 41600 \\
\hline 30 & & 113.1 & 217.9 & 344.4 & 6.58 & 3.42 & 38600 \\
\hline & gemiddeld & 114.4 & 217.7 & 355.9 & 6.40 & 3.50 & 38800 \\
\hline
\end{tabular}


Tabel B.2 Overzicht van de karakteristieke grootheden van het druppelgroottespectrum, gemiddelde druppelsnelheid en aantal gemeten druppels voor de HTA-doppen bij verschillende combinaties van vloeistofdruk en luchtdruk; gemeten met PDPA.

\begin{tabular}{|c|c|c|c|c|c|c|c|c|c|c|}
\hline Run & Datum & $\begin{array}{c}\text { Vloeistofdruk } \\
\text { [kPa] }\end{array}$ & $\begin{array}{l}\text { Luchtdruk } \\
\text { [kPa] }\end{array}$ & Dopnr & $\begin{array}{l}\text { Dv10 } \\
{[\mu \mathrm{m}]}\end{array}$ & $\begin{array}{l}\text { Dv50 } \\
{[\mu \mathrm{m}]}\end{array}$ & $\begin{array}{l}\text { Dv9o } \\
{[\mu \mathrm{m}]}\end{array}$ & $\begin{array}{l}V_{100} \\
{[\%]}\end{array}$ & $\begin{array}{c}V_{\mathrm{gem}} \\
{[\mathrm{m} / \mathrm{s}]}\end{array}$ & $\begin{array}{c}\text { Aantal } \\
\text { druppels }\end{array}$ \\
\hline 1 & $12-3-2020$ & 200 & 30 & 8 & 326.7 & 702.0 & 1170.1 & 0.38 & 1.47 & 9900 \\
\hline 2 & & & & & 316.9 & 706.4 & 1222.2 & 0.44 & 1.46 & 11000 \\
\hline 3 & & & & & 324.4 & 701.8 & 1182.7 & 0.38 & 1.46 & 10000 \\
\hline 4 & $13-3-2020$ & & & 1 & 317.7 & 690.3 & 1203.9 & 0.38 & 1.49 & 10600 \\
\hline 5 & & & & & 311.0 & 682.0 & 1218.8 & 0.47 & 1.43 & 11900 \\
\hline 6 & & & & & 310.8 & 668.2 & 1324.9 & 0.37 & 1.51 & 11200 \\
\hline 7 & & & & 4 & 321.6 & 693.2 & 1279.8 & 0.36 & 1.44 & 9200 \\
\hline 8 & & & & & 309.4 & 680.1 & 1125.6 & 0.41 & 1.47 & 10800 \\
\hline 9 & & & & & 306.6 & 677.4 & 1187.5 & 0.39 & 1.50 & 10700 \\
\hline & gemiddeld & & & & 316.1 & 689.0 & 1212.8 & 0.40 & 1.47 & 10600 \\
\hline 1 & $13-3-2020$ & 200 & 35 & 4 & 283.0 & 600.2 & 1017.7 & 0.53 & 1.55 & 14000 \\
\hline 2 & & & & & 279.9 & 602.8 & 1149.5 & 0.53 & 1.53 & 14400 \\
\hline 3 & & & & & 281.2 & 615.4 & 1141.9 & 0.60 & 1.48 & 15700 \\
\hline 4 & $16-3-2020$ & & & 8 & 305.5 & 675.6 & 1199.3 & 0.42 & 1.58 & 12800 \\
\hline 5 & & & & & 293.5 & 629.5 & 1087.9 & 0.47 & 1.61 & 12700 \\
\hline 6 & & & & & 292.4 & 659.5 & 1110.2 & 0.45 & 1.61 & 12700 \\
\hline 7 & & & & 1 & 267.2 & 576.9 & 1054.1 & 0.61 & 1.54 & 15800 \\
\hline 8 & & & & & 276.3 & 593.0 & 1061.9 & 0.50 & 1.57 & 14100 \\
\hline 9 & & & & & 281.1 & 585.2 & 1043.7 & 0.54 & 1.53 & 14500 \\
\hline & gemiddeld & & & & 284.5 & 615.3 & 1096.2 & 0.52 & 1.56 & 14100 \\
\hline 1 & $16-3-2020$ & 200 & 50 & 1 & 205.7 & 461.8 & 837.7 & 1.01 & 1.76 & 16100 \\
\hline 2 & & & & & 203.0 & 469.7 & 938.9 & 1.15 & 1.66 & 17500 \\
\hline 3 & & & & & 204.4 & 441.9 & 809.4 & 1.15 & 1.79 & 16400 \\
\hline 4 & & & & 4 & 232.4 & 498.5 & 953.1 & 0.78 & 1.83 & 12800 \\
\hline 5 & & & & & 220.8 & 487.8 & 844.9 & 0.86 & 1.80 & 13700 \\
\hline 6 & & & & & 222.1 & 497.2 & 886.5 & 0.88 & 1.76 & 14100 \\
\hline 7 & & & & 8 & 228.8 & 501.9 & 929.3 & 0.91 & 1.80 & 14400 \\
\hline 8 & & & & & 221.9 & 484.5 & 872.2 & 0.95 & 1.81 & 15100 \\
\hline 9 & & & & & 231.3 & 507.8 & 900.0 & 0.73 & 1.85 & 13700 \\
\hline & gemiddeld & & & & 218.9 & 483.4 & 885.8 & 0.94 & 1.78 & 14900 \\
\hline 1 & $6-3-2020$ & 200 & 90 & 8 & 133.9 & 308.8 & 603.9 & 4.00 & 2.20 & 28000 \\
\hline 2 & & & & & 132.5 & 308.5 & 571.9 & 4.35 & 2.15 & 28500 \\
\hline 3 & & & & & 135.6 & 307.8 & 546.9 & 4.05 & 2.21 & 26500 \\
\hline 4 & & & & 1 & 130.4 & 288.2 & 549.5 & 4.23 & 2.06 & 29200 \\
\hline 5 & & & & & 132.1 & 295.1 & 580.4 & 4.08 & 2.13 & 28900 \\
\hline 6 & & & & & 131.0 & 295.4 & 567.6 & 4.30 & 2.13 & 30200 \\
\hline 7 & & & & 4 & 139.6 & 313.2 & 580.1 & 3.53 & 2.16 & 24500 \\
\hline 8 & & & & & 135.5 & 305.6 & 593.1 & 3.79 & 2.04 & 26300 \\
\hline 9 & & & & & 138.9 & 320.2 & 609.8 & 3.74 & 2.16 & 27000 \\
\hline & gemiddeld & & & & 134.4 & 304.8 & 578.1 & 4.01 & 2.14 & 27700 \\
\hline
\end{tabular}


Tabel B.3 Overzicht van de karakteristieke grootheden van het druppelgroottespectrum, gemiddelde druppelsnelheid en aantal gemeten druppels voor de HTA-doppen bij verschillende combinaties van vloeistofdruk en luchtdruk; gemeten met PDPA.

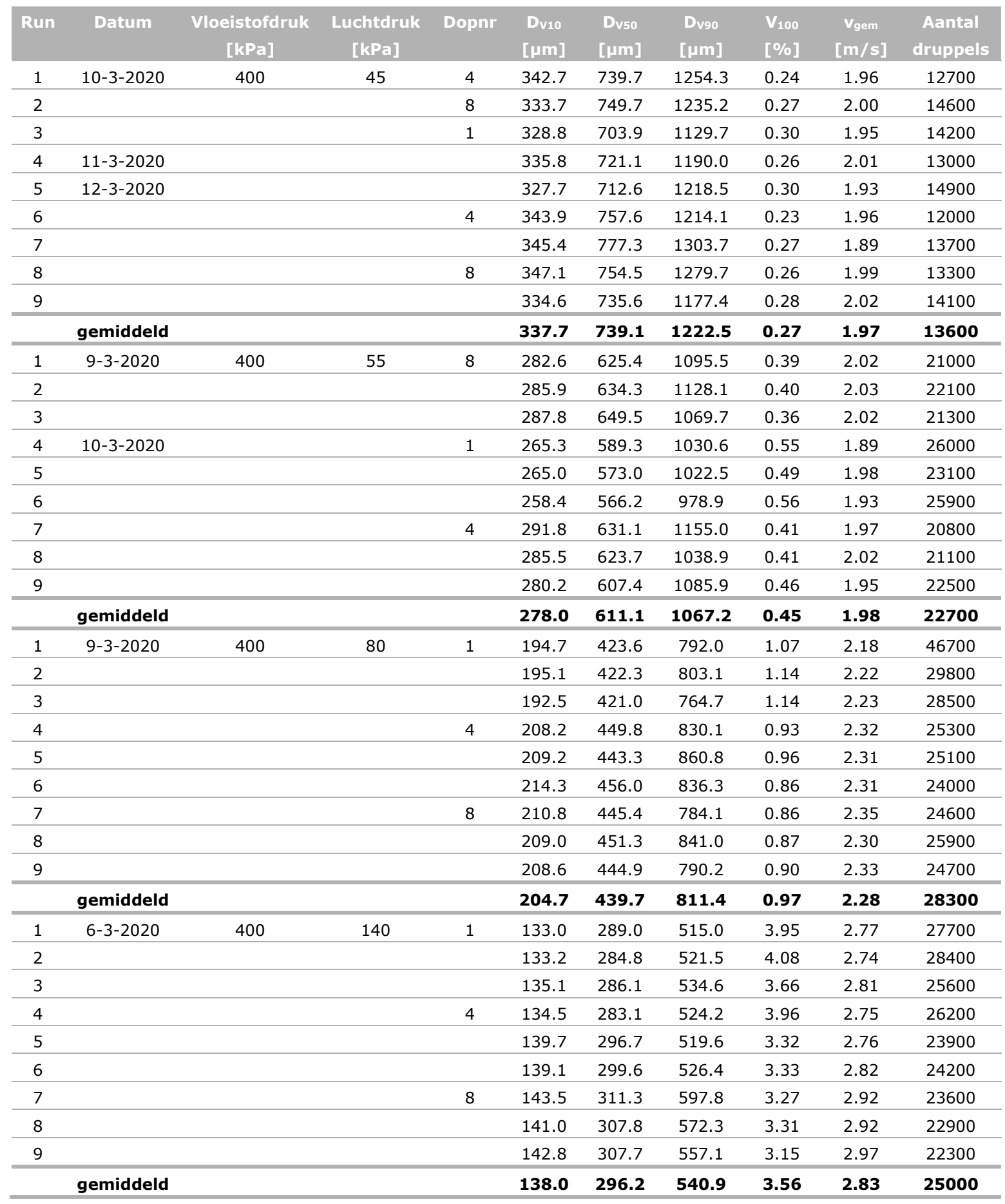


Tabel B.4 Overzicht van de karakteristieke grootheden van het druppelgroottespectrum, gemiddelde druppelsnelheid en aantal gemeten druppels voor de HTA-doppen bij verschillende combinaties van vloeistofdruk en luchtdruk; gemeten met PDPA.

\begin{tabular}{|c|c|c|c|c|c|c|c|c|c|c|}
\hline Run & Datum & $\begin{array}{c}\text { Vloeistofdruk } \\
\text { [kPa] }\end{array}$ & $\begin{array}{l}\text { Luchtdruk } \\
\text { [kPa] }\end{array}$ & Dopnr & $\begin{array}{l}\text { Dv10 } \\
{[\mu \mathrm{m}]}\end{array}$ & $\begin{array}{l}\text { Dv50 } \\
{[\mu \mathrm{m}]}\end{array}$ & $\begin{array}{c}\text { Dvgo } \\
{[\mu \mathrm{m}]}\end{array}$ & $\begin{array}{l}V_{100} \\
{[\%]}\end{array}$ & $\begin{array}{c}V_{g e m} \\
{[\mathrm{~m} / \mathrm{s}]}\end{array}$ & $\begin{array}{c}\text { Aantal } \\
\text { druppels }\end{array}$ \\
\hline 1 & $2-3-2020$ & 600 & 90 & 1 & 238.1 & 509.7 & 890.1 & 0.57 & 2.45 & 19400 \\
\hline 2 & & & & & 232.7 & 496.8 & 892.7 & 0.63 & 2.47 & 26600 \\
\hline 3 & & & & & 221.6 & 464.2 & 861.0 & 0.70 & 2.48 & 30500 \\
\hline 4 & & & & 4 & 234.0 & 497.4 & 853.5 & 0.66 & 2.48 & 22300 \\
\hline 5 & & & & & 229.6 & 499.3 & 860.3 & 0.66 & 2.52 & 22100 \\
\hline 6 & & & & & 227.8 & 480.4 & 832.2 & 0.70 & 2.49 & 21800 \\
\hline 7 & $3-3-2020$ & & & 8 & 248.8 & 517.0 & 916.7 & 0.52 & 2.60 & 17400 \\
\hline 8 & & & & & 239.1 & 515.0 & 907.6 & 0.62 & 2.61 & 21000 \\
\hline 9 & & & & & 241.1 & 511.5 & 901.3 & 0.57 & 2.57 & 20100 \\
\hline & gemiddeld & & & & 234.8 & 499.0 & 879.5 & 0.63 & 2.52 & 22400 \\
\hline 1 & $3-3-2020$ & 600 & 100 & 4 & 215.8 & 447.2 & 811.2 & 0.81 & 2.63 & 24400 \\
\hline 2 & & & & & 206.2 & 438.2 & 817.8 & 0.94 & 2.62 & 27500 \\
\hline 3 & & & & & 210.7 & 452.4 & 803.3 & 0.93 & 2.53 & 27200 \\
\hline 4 & & & & 8 & 211.0 & 446.6 & 805.6 & 0.93 & 2.64 & 26500 \\
\hline 5 & & & & & 210.6 & 446.0 & 821.8 & 0.94 & 2.62 & 26900 \\
\hline 6 & & & & & 216.2 & 463.0 & 825.7 & 0.83 & 2.68 & 26200 \\
\hline 7 & & & & 1 & 200.4 & 423.2 & 737.8 & 0.96 & 2.65 & 28200 \\
\hline 8 & & & & & 200.5 & 424.4 & 779.9 & 1.01 & 2.63 & 27700 \\
\hline 9 & & & & & 207.7 & 432.9 & 791.7 & 0.95 & 2.68 & 26500 \\
\hline & gemiddeld & & & & 208.8 & 441.5 & 799.4 & 0.92 & 2.63 & 26800 \\
\hline 1 & $5-3-2020$ & 600 & 200 & 1 & 125.0 & 253.6 & 479.7 & 4.89 & 3.34 & 41600 \\
\hline 2 & & & & & 123.8 & 259.3 & 475.7 & 5.08 & 3.28 & 29100 \\
\hline 3 & & & & & 125.2 & 264.0 & 499.2 & 4.88 & 3.25 & 27400 \\
\hline 4 & & & & 4 & 131.2 & 278.3 & 541.3 & 4.20 & 3.28 & 23000 \\
\hline 5 & & & & & 124.0 & 259.8 & 473.1 & 5.07 & 3.25 & 26100 \\
\hline 6 & & & & & 130.0 & 263.5 & 481.4 & 4.24 & 3.34 & 23300 \\
\hline 7 & & & & 8 & 128.7 & 270.4 & 498.0 & 4.56 & 3.42 & 25900 \\
\hline 8 & & & & & 130.2 & 274.0 & 507.4 & 4.35 & 3.37 & 24200 \\
\hline 9 & & & & & 130.9 & 274.5 & 502.7 & 4.20 & 3.49 & 24300 \\
\hline & gemiddeld & & & & 127.7 & 266.4 & 495.4 & 4.61 & 3.34 & 27200 \\
\hline
\end{tabular}




\section{Bijlage 2 Overzicht aanvullende metingen van druppelgroottes}

Overzichten van druppelgroottemetingen van HTA-doppen voor aanvullende combinaties van vloeistofdruk en luchtdruk. Bij deze metingen zijn de drie geselecteerde doppen in enkelvoud gemeten; Tabel B.5. Verder is in Tabel B.6 en overzicht gegeven van metingen van HTA-doppen zonder luchttoevoer. Ook deze metingen zijn minder uitgebreid gedaan, omdat het een toepassing als randmodus-dop betreft en niet een volvelds toepassing in deze studie.

Tabel B.5 Overzicht van de karakteristieke grootheden van het druppelgroottespectrum, gemiddelde druppelsnelheid en aantal gemeten druppels voor de HTA-doppen bij verschillende combinaties van vloeistofdruk en luchtdruk; gemeten met PDPA.

\begin{tabular}{|c|c|c|c|c|c|c|c|c|c|c|}
\hline Run & Datum & $\begin{array}{c}\text { Vloeistofdruk } \\
\text { [kPa] }\end{array}$ & $\begin{array}{l}\text { Luchtdruk } \\
\text { [kPa] }\end{array}$ & Dopnr & $\begin{array}{l}\text { Dv10 } \\
{[\mu \mathrm{m}]}\end{array}$ & $\begin{array}{l}\text { Dv50 } \\
{[\mu \mathrm{m}]}\end{array}$ & $\begin{array}{l}\text { Dvgo } \\
{[\mu \mathrm{m}]}\end{array}$ & $\begin{array}{l}V_{100} \\
{[\%]}\end{array}$ & $\begin{array}{c}\text { Vgem } \\
{[\mathrm{m} / \mathrm{s}]}\end{array}$ & $\begin{array}{l}\text { Aantal } \\
\text { druppels }\end{array}$ \\
\hline 1 & $18-3-2020$ & 200 & 60 & 1 & 187.2 & 431.8 & 766.0 & 1.38 & 1.89 & 13300 \\
\hline 3 & & & & 8 & 183.8 & 407.4 & 756.4 & 1.48 & 1.89 & 12700 \\
\hline & gemiddeld & & & & 182.8 & 420.0 & 764.5 & 1.48 & 1.90 & 13300 \\
\hline 2 & & & & 1 & 147.9 & 338.5 & 660.9 & 2.94 & 2.03 & 21800 \\
\hline 3 & & & & 4 & 157.0 & 361.8 & 734.8 & 2.39 & 2.14 & 19300 \\
\hline & gemiddeld & & & & 149.4 & 341.7 & 673.3 & 2.75 & 2.08 & 21000 \\
\hline 1 & $18-3-2020$ & 400 & 60 & 1 & 260.1 & 579.6 & 1010.5 & 0.57 & 1.98 & 11000 \\
\hline 1 & $18-3-2020$ & 400 & 100 & 4 & 179.2 & 386.1 & 695.3 & 1.51 & 2.56 & 13300 \\
\hline 2 & & & & 8 & 180.7 & 386.8 & 676.1 & 1.50 & 2.60 & 13900 \\
\hline 3 & & & & 1 & 166.0 & 350.0 & 656.2 & 1.81 & 2.52 & 15700 \\
\hline & gemiddeld & & & & 175.3 & 374.3 & 675.9 & 1.61 & 2.56 & 14300 \\
\hline 1 & $18-3-2020$ & 400 & 120 & 8 & 155.4 & 329.1 & 597.8 & 2.38 & 2.77 & 18100 \\
\hline 2 & & & & 1 & 144.0 & 309.0 & 582.3 & 2.99 & 2.65 & 21700 \\
\hline 3 & & & & 4 & 150.5 & 325.5 & 582.2 & 2.60 & 2.66 & 18700 \\
\hline & gemiddeld & & & & 150.0 & 321.2 & 587.4 & 2.66 & 2.69 & 19500 \\
\hline 2 & & & & 8 & 156.3 & 330.9 & 580.7 & 2.26 & 3.12 & 23700 \\
\hline 3 & & & & 1 & 147.4 & 308.6 & 543.8 & 2.81 & 2.89 & 27800 \\
\hline & gemiddeld & & & & 152.8 & 321.5 & 566.3 & 2.46 & 3.00 & 24800 \\
\hline
\end{tabular}


Tabel B.6 Overzicht van de karakteristieke grootheden van het druppelgroottespectrum, gemiddelde druppelsnelheid en aantal gemeten druppels voor de HTA-doppen zonder luchtdruk, te gebruiken als randmodus-doppen; gemeten met PDPA.

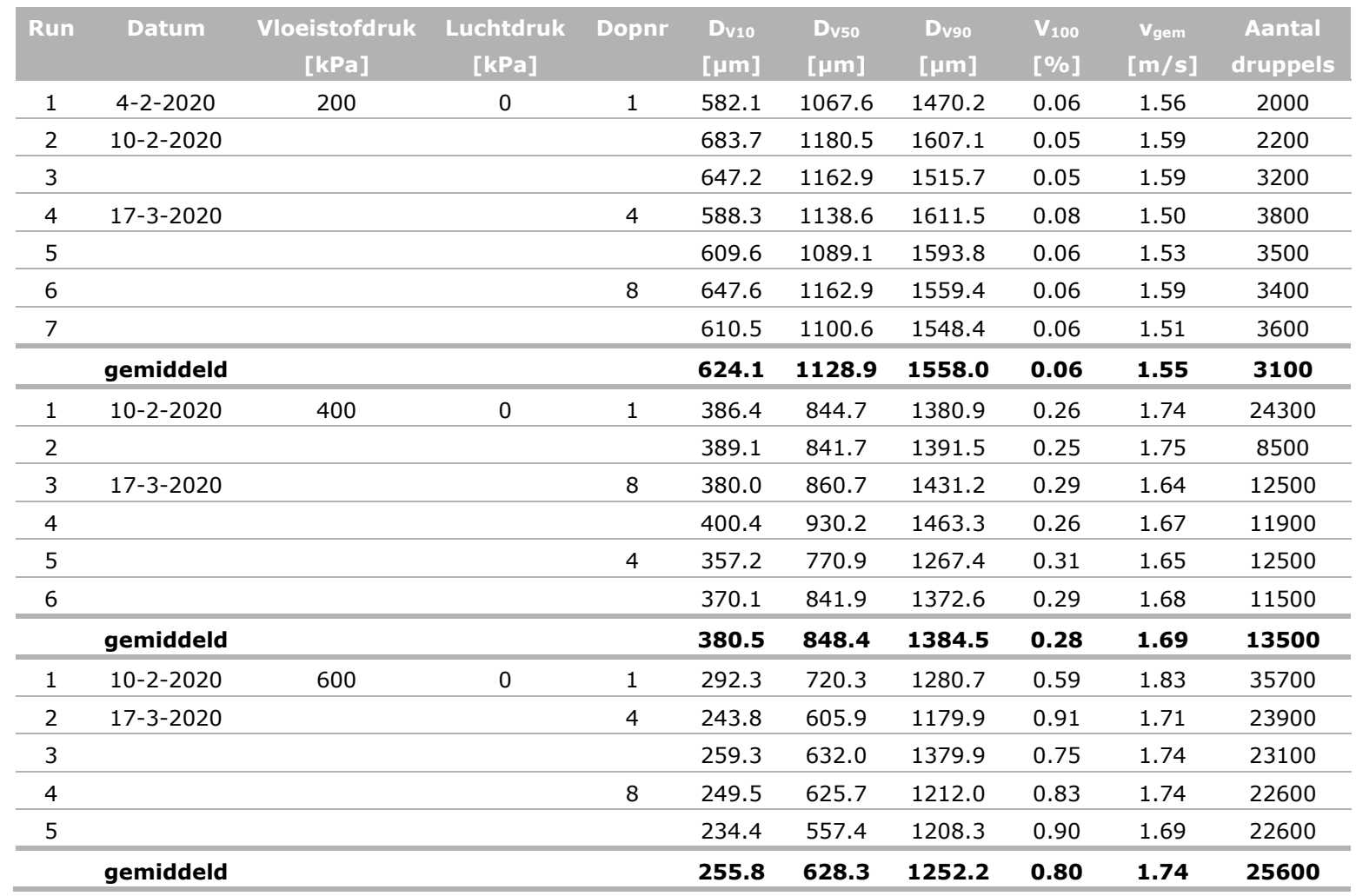


Correspondentie adres voor dit rapport: Postbus 16

6700 AA Wageningen

T 0317480700

www.wur.nl/plant-research

Rapport WPR-1022
De missie van Wageningen University \& Research is 'To explore the potential of nature to improve the quality of life'. Binnen Wageningen University \& Research bundelen Wageningen University en gespecialiseerde onderzoeksinstituten van Stichting Wageningen Research hun krachten om bij te dragen aan de oplossing van belangrijke vragen in het domein van gezonde voeding en leefomgeving. Met ongeveer 30 vestigingen, 6.500 medewerkers ( $5.500 \mathrm{fte}$ ) en 12.500 studenten behoort Wageningen University \& Research wereldwijd tot de aansprekende kennisinstellingen binnen haar domein. De integrale benadering van de vraagstukken en de samenwerking tussen verschillende disciplines vormen het hart van de unieke Wageningen aanpak. 



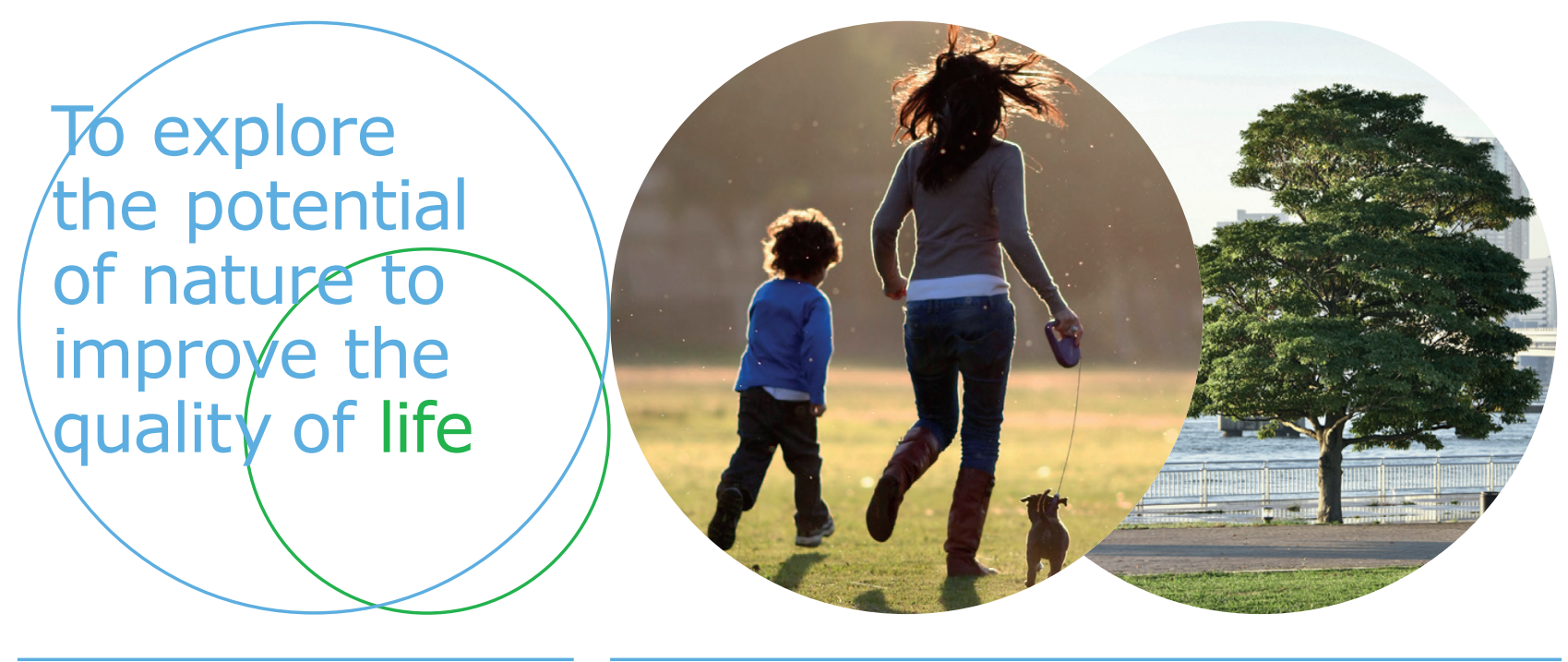

Correspondentie adres voor dit rapport: Postbus 16

6700 AA Wageningen

T 0317480700

www.wur.nl/plant-research

Rapport WPR-1022
De missie van Wageningen University \& Research is 'To explore the potential of nature to improve the quality of life'. Binnen Wageningen University \& Research bundelen Wageningen University en gespecialiseerde onderzoeksinstituten van Stichting Wageningen Research hun krachten om bij te dragen aan de oplossing van belangrijke vragen in het domein van gezonde voeding en leefomgeving. Met ongeveer 30 vestigingen, 6.500 medewerkers ( $5.500 \mathrm{fte}$ ) en 12.500 studenten behoort Wageningen University \& Research wereldwijd tot de aansprekende kennisinstellingen binnen haar domein. De integrale benadering van de vraagstukken en de samenwerking tussen verschillende disciplines vormen het hart van de unieke Wageningen aanpak. 